\title{
Physical-geographic factors of terrain trafficability of military vehicles according to Western World methodologies
}

\section{Fizičko-geografski čimbenici terenske prohodnosti vojnih vozila prema metodologijama zapadnoga svijeta}

This paper analyses the existing state, limitations, and possibilities for research of physical-geographic factors in the context of terrain trafficability of military vehicles in order to support the military decision-making process regarding planning movements of military forces. This paper shows which models and research methodologies were used to ascertain how physical-geographical factors influence vehicle cross-country mobility. Research has shown that slope has been used most frequently as a parameter, followed by soil properties, surface roughness, watercourses, vegetation types, and climatic-meteorological conditions. The quality of the results achieved so far has been largely determined by the quality and accuracy of the input data and by the various methods used in the models. Recent studies have shown that the Geographic Information System (GIS) unifies the issues determining vehicle terrain trafficability, as it displays all possibilities in a single platform.

Key words: vehicle terrain trafficability, cross-country mobility, GIS modelling, military geography
U ovom se radu analizira postojeće stanje, ograničenja i mogućnosti istraživanja fizičko-geografskih čimbenika u kontekstu terenske prohodnosti vojnih vozila u svrhu potpore procesa donošenja vojnih odluka prilikom planiranja pokreta vojnih snaga. Rad prikazuje do sada korištene tipove modela, metodologije i načine prikaza rezultata utjecaja fizičko-geografskih čimbenika na pokretljivost vozila. Provedena istraživanja pokazala su da je $\mathrm{u}$ dosadašnjim istraživanjima najčešce korišten parametar nagib padina, potom fizičke osobine tla, hrapavost površine, vodotoci, tipovi vegetacije i klimatsko-meteorološki uvjeti. Kvaliteta rezultata dosadašnjih istraživanja određena je kvalitetom i točnošću ulaznih podataka te primjenjivanim metodama korištenima u modelima. U novijim istraživanjima geografski informacijski sustav (GIS) autorima omogućuje sjedinjavanje cjelokupne problematike utvrdivanja terenske prohodnosti vozila jer objedinjuje sve mogućnosti na jedinstvenoj platformi.

Ključne riječi: terenska prohodnost vozila, terenska mobilnost vozila, GIS modeliranje, vojna geografija 


\section{Introduction}

The contemporary employment of the ground component of the armed forces, both in war and various peace operations but also as assistance to the civilian population in times of crisis (e.g. natural disasters), includes a wide range of analysis of vehicle terrain trafficability. The significance of armoured and mechanised forces has been progressively increasing since the First World War. At all levels of warfare, which incorporates tactical, operational, and strategic elements, the definition of mobility corridors ${ }^{1}$ of mobile forces is one of the key tasks in the military decision-making process. Therefore, the methodology of thematic cartography interpretation of vehicle trafficability has always been closely related to the technical and tactical development of vehicles and modern methods of geospatial terrain analysis.

The term "terrain trafficability" is used to determine the limiting factors that affect the mobility of vehicles outside the road infrastructure (Production of Cross-Country, 1959; Grabau, 1964; Military Geographic Intelligence, 1972; Schreier and Lavkulich, 1978; Donlon and Forbus, 1999; Wong, 2001; Saarilahti, 2002; Birkel, 2003; Rybanský, 2003; Jones et al., 2004; Gumoś, 2005; Kourdian, 2009; Hofmann et al., 2013; Hohmann et al., 2013).

When discussing the abilities and limits of manoeuvring characteristics of vehicles outside the road infrastructure, several terms and names with similar meaning are used. In the literature, we can find the terms such as cross-country mobility (CCM) (Production of Cross-Country, 1959; Jurkat et al., 1975; Pearson and Wright, 1980; Mintzer and Messmore, 1984; Hetherington and Smith, 1986; Bruzese, 1989; Planning and design, 1994; Grogan, 2009; Shoop et al., 2006; Rybansky, 2014; Talhofer et al., 2015), cross-country movement (Jurkat i dr., 1975; Haley i dr., 1979b; Pearson i Wright, 1980; Wynn, 1985; Terrain Analysis, 1990; Ahlvin i Haley, 1992; Donlon i Forbus, 1999; Pahernik i dr., 2006; Rybansky, 2014), cross-country trafficability (Donlon and Forbus, 1999; Gumoś, 2005) and vehicle manoeuvrability. In this paper, the term "vehicle terrain trafficability" will be used

1 "Mobility corridors are areas where a force will be canalized due to terrain constrictions. The mobility corridor itself is relatively free of obstacles and allows military forces to capitalize on the principles of mass and speed." (Intelligence preparation, 1994, 2-18).
Uvod

Suvremena uporaba kopnene sastavnice oružanih snaga, kako u ratnim tako i u različitim mirovnim operacijama, ali i potpori civilnom stanovništvu, uključuje širok spektar analiza terenske prohodnosti vozila. Važnost oklopno-mehaniziranih snaga progresivno raste od Prvoga svjetskog rata do danas. $\mathrm{Na}$ svim razinama ratovanja koje uključuju taktičke, operativne i strateške elemente, definiranje koridora mobilnosti ${ }^{1}$ tih snaga jedna je od ključnih zadaća u procesu donošenja vojne odluke. Pri tome je metodologija izrade različitih kartografskih tematskih podloga prohodnosti vozila bila u jasnoj korelaciji s taktičko-tehnološkim razvojem vozila te u primjeni suvremenih metoda geoprostorne analize zemljišta.

Pojam „prohodnost terena” upotrebljava se pri određivanju ograničavajućih čimbenika koji utječu na pokretljivost vozila izvan cestovne infrastrukture (Production of Cross-Country, 1959; Grabau, 1964; Military Geographic Intelligence, 1972; Schreier and Lavkulich, 1978; Donlon i Forbus, 1999; Wong, 2001; Saarilahti, 2002; Birkel, 2003; Rybanský, 2003; Jones i dr., 2004; Gumoś, 2005; Kourdian, 2009; Hofmann i dr., 2013; Hohmann i dr., 2013).

U opisivanju sposobnosti i ograničavajućih voznih osobina vozila izvan cestovne infrastrukture upotrebljava se nekoliko istoznačnica i pojmova bliskoga značenja. Tako u radovima nalazimo nazive terenska mobilnost (engl. cross-country mobility CCM) (Production of Cross-Country, 1959; Jurkat i dr., 1975; Pearson i Wright, 1980; Mintzer i Messmore, 1984; Hetherington i Smith, 1986; Bruzese, 1989; Planning and design, 1994; Grogan, 2009; Shoop i dr., 2006; Rybansky, 2014; Talhofer i dr., 2015), terenska pokretljivost (engl. cross-country movement) (Jurkat i dr., 1975; Haley i dr., 1979b; Pearson i Wright, 1980; Wynn, 1985; Terrain Analysis, 1990; Ahlvin i Haley, 1992; Donlon i Forbus, 1999; Pahernik i dr., 2006; Rybansky, 2014), terenska prometnost (engl. cross-country trafficability) (Donlon i Forbus, 1999; Gumoś, 2005) i manevarska sposob-

\footnotetext{
1 „Koridori mobilnosti su područja ograničenog i kanaliziranog kretanja snaga na zemljištu. Koridor mobilnosti je područje bez većih prepreka, odnosno omogućava upotrebu snaga u njihovu potpunom potencijalu." (Intelligence preparation, 1994, 2-18).
} 
because it relates to the terrain. The term indicates a description of morphometry, structure, and phenomena on terrain that defines vehicle movement possibilities. The terms cross-country mobility, cross-country movement, cross-country trafficability, and vehicle manoeuvrability are used primarily to describe technical and tactical capabilities of vehicles in terms of movement outside road infrastructure.

Cross-country mobility of vehicles is determined by the presence of infrastructure, physical-geographical features, driver experience, and the technical and tactical characteristics of the vehicle in question. Determining the presence and structure of the physical-geographic factors, responsible for vehicle terrain trafficability, is the fundamental precondition for terrain trafficability prediction. Physical-geographic elements that influence vehicle mobility on terrain are the relief, water, soil, vegetation, and climatic-meteorological conditions (Production of Cross-Country, 1959; Grabau, 1964; Schreier and Lavkulich, 1978; Pearson and Wright, 1980; Mohamad Rabab, 2002; Birkel, 2003; Rybanský, 2003; Gustafsson and Hägerstrand, 2005; Grogan, 2009; Borisov et al., 2010; Pimpa et al., 2014; Rybanský et al., 2015). Defining vehicle terrain trafficability is necessary in order to inform military commanders about the mobility constraints vehicles may face in a given area, enabling them to make assumptions about possible directions of vehicle movement. Following the implementation of different methods, analysis of the terrain becomes an integral part of the Intelligence preparation of the battlefield (IPB) and represents a key element in the preparation of any military operation (Loomer, 1987; Wawer et al., 2003). The primary goal of vehicle terrain trafficability assessment is to determine to what degree a particular factor and/or combination of factors might slow a vehicle down in relation to its maximum possible velocity. The factors that define vehicle terrain trafficability are the existing road network, built-up areas, morphological characteristics of the terrain, and weather conditions. Military geographic analysis of the terrain is a part of the $\mathrm{OAKOC}^{2}$ procedures within the mil-

2 OAKOC is an abbreviation for the process used by North Atlantic Treaty Organization (NATO) member states, during which the terrain is being analysed for the purposes of IPB in the military planning process, where possibilities of observation and fields of fire are determined, as well as the avenues and corridors of mobility, key terrain, obstructions, cover and concealment of military forces. nost vozila (engl. vebicle maneuverability) U ovom će se radu upotrebljavati naziv terenska prohodnost vozila jer se on odnosi na zemljište. Pojam sadržava opis morfometrije, struktura i pojava na zemljištu koje definiraju mogućnost pokreta vozila. Pojmovi mobilnost, pokretljivost, prometnost i manevarska sposobnost vozila se prije svega rabe prilikom opisivanja tehničko-taktičkih sposobnosti vozila za kretanje po zemljištu izvan cestovne infrastrukture.

Terenska mobilnost vozila uvjetovana je prisutnošću izgrađene infrastrukture, fizičko-geografskih struktura, oblika i pojava, iskustvom vozača i tehničko-taktičkim obilježjima vozila. Utvrđivanje prisutnosti i strukture fizičko-geografskih čimbenika, od kojih zavisi prohodnost vozila, osnovni je preduvjet predviđanja terenske prohodnosti vozila. Fizičko-geografski elementi koji uvjetuju pokretljivost vozila na zemljištu su reljef, vode, tlo, vegetacija i klimatsko-meteorološke prilike (Production of Cross-Country, 1959; Grabau, 1964; Schreier i Lavkulich, 1978; Pearson i Wright, 1980; Mohamad Rabab, 2002; Birkel, 2003; Rybanský, 2003; Gustafsson i Hägerstrand, 2005; Grogan, 2009; Borisov i dr., 2010; Pimpa i dr., 2014; Rybanský i dr., 2015). Utvrđivanje terenske prohodnosti vozila potrebno je kako bi se zapovjednicima vojnih snaga omogućio uvid u ograničenja pokretljivosti vozila i stvorile pretpostavke o mogućim smjerovima kretanja vlastitih i protivničkih snaga. Primjenom iskustvenih i znanstvenih metoda, analiza zemljišta postaje integralni dio obavještajne pripreme bojišta te je ključan element pripreme svake vojne operacije (Loomer, 1987; Wawer i dr., 2003). Primarni je cilj pri utvrđivanju terenske prohodnosti vozila utvrditi u kojoj mjeri pojedini čimbenik i/ili kombinacija čimbenika usporavaju vozilo prilikom kretanja u odnosu na njegovu maksimalnu moguću brzinu kretanja. Čimbenici koji definiraju pokretljivost vozila na zemljištu su postojeća mreža prometnica, izgrađeni objekti, morfološka obilježja zemljišta i meteorološki uvjeti. Vojno-geografska analiza zemljišta dio je $\mathrm{OAKOC}^{2}$ procedure unutar procesa

2 OAKOC (engl. Observation/fields of fire, Avenues of approach, Key terrain, Obstructions, Cover and concealment) je kratica za proces kojim se služe zemlje članice Sjevernoatlantskoga saveza (NATO) i tijekom kojega se analizira zemljište u svrhu obavještajne pripreme bojnoga polja tijekom procesa planiranja vojnih operacija, gdje se utvrđuju sposobnost motrenja i polja vatri, avenije prilaza - koridori mobilnosti, ključni tereni, prepreke te zaštita i prikrivanje vojnih snaga.
H Heštera

M. Pahernik

Physicalgeographic factors of terrain trafficability of military vehicles according to Western World methodologies

Fizičko-geografski čimbenici terenske prohodnosti vojnih vozila prema metodologijama zapadnoga svijeta 
GEOGRAFSKI

GLASNIK

80/2, 5-31 (2018.) itary decision-making process (Military Geographic Intelligence, 1972; Terrain Analysis, 1990). The main precondition for successful planning and enforcement of movement of military forces is based on collecting, processing, and analysing terrain data and emerging weather conditions using a structured database (Bruzese, 1989; Mintzer and Messmore, 1984). Terrain trafficability for vehicles is determined in order to define possible routes and directions for vehicle movement, as well as mobility corridors and avenues of approach ${ }^{3}$. The ultimate goal of military analysts is the creation of a vehicle trafficability map, allowing accurate plans for vehicle movement to be made. GIS is one of the tools used in military structures for decision-making, and for civilian and humanitarian purposes (Donlon and Forbus, 1999; Lubello, 2008; Laskey et al., 2010).

\section{Historical review}

The presence and impact of physical-geographic features on vehicle terrain trafficability is a study subject of numerous professions and scientific disciplines. Defining vehicle terrain trafficability as a part of military terrain analysis is a complex analytical process that requires a comprehensive multidisciplinary approach (Military Geographic Intelligence, 1972) (Fig. 1).

Understanding of limits and technical/tactical capabilities of vehicle movement on terrain as a subject of study was recognised and applied initially in military science (Johnson, 1921; Malm, 2018). The importance of understanding terrain characteristics in military operation planning has been recognised as a decisive factor for successful military operations for millennia (Jomini, 1838; Clausewitz, 1997; Tzu, 2009). Until the First and Second World Wars, military analysis of the terrain was focused exclusively on the use of military forces at the strategic level, neglecting the lowest tactical levels of warfare. Although there had been a certain awareness of the importance of understanding the physical properties of terrain throughout the history of warfare, research of vehicle terrain trafficability by the wider scientific community was only initiated after the

\footnotetext{
3 "An Avenue of approach is an air or ground route of an attacking force of a given size leading to its objective or to key terrain in its path. A group of mobility corridors forms an Avenue of approach." (Intelligence preparation, 1994, 2-18).
}

donošenja vojnih odluka (Military Geographic Intelligence, 1972; Terrain Analysis, 1990). Osnovni je preduvjet uspješnoga planiranja i provedbe pokreta vojnih snaga prikupljanje, obrada i analiza podataka o zemljištu i nadolazećim meteorološkim prilikama kroz strukturiranu bazu podataka (Bruzese, 1989; Mintzer i Messmore, 1984). Terenska prohodnost vozila istražuje se kako bi se definirale moguće rute i smjerovi kretanja vozila, odnosno kako bi se definirali koridori mobilnosti i avenije prilaza. ${ }^{3}$ Krajnji je cilj vojnih analitičara stvaranje karte prohodnosti vozila, temeljem koje se potom može planirati kretanje vozila. GIS, kao jedan od alata prilikom donošenja odluka, koristi se u vojnim strukturama te u civilne i humanitarne svrhe (Donlon i Forbus, 1999; Lubello, 2008; Laskey i dr., 2010).

\section{Povijesni pregled}

Prisutnost i utjecaj fizičko-geografskih značajka prostora na terensku prohodnost vozila predmet je proučavanja brojnih struka i znanstvenih disciplina. Definiranje terenske prohodnosti vozila u sklopu vojne analize zemljišta kompleksan je analitički proces koji zahtijeva sveobuhvatan multidisciplinaran pristup (Military Geographic Intelligence, 1972) (sl. 1).

Poznavanje graničnih tehničko-taktičkih mogućnosti kretanja vozila na zemljištu kao predmet proučavanja prepoznato je i primijenjeno prvotno u vojnoj znanosti (Johnson, 1921; Malm, 2018). Poznavanje obilježja zemljišta prilikom planiranja vojnih operacija prepoznato je kao odlučujući čimbenik uspješna ishoda ratnih operacija još od antičkih vremena (Jomini, 1838; Clausewitz, 1997; Tzu, 2009). Do svjetskih ratova vojno-geografska analiza zemljišta bila je u većoj mjeri usmjerena na upotrebu snaga na strateškoj razini, pri čemu je zanemarena upotreba snaga na najnižoj taktičkoj razini ratovanja. Iako je postojala svijest o važnosti poznavanja fizičkih obilježja zemljišta kroz cijelu povijest ratovanja, sistematizirano proučavanje prohodnosti terena u širokoj znanstvenoj zajednici ak-

\footnotetext{
3 „Avenija prilaza je zračna ili kopnena ruta smjera napada snaga određene jačine koja vodi ka ključnom terenu na zemljištu. Grupa koridora mobilnosti čini aveniju prilaza." (Intelligence preparation, 1994, 2-18)
} 


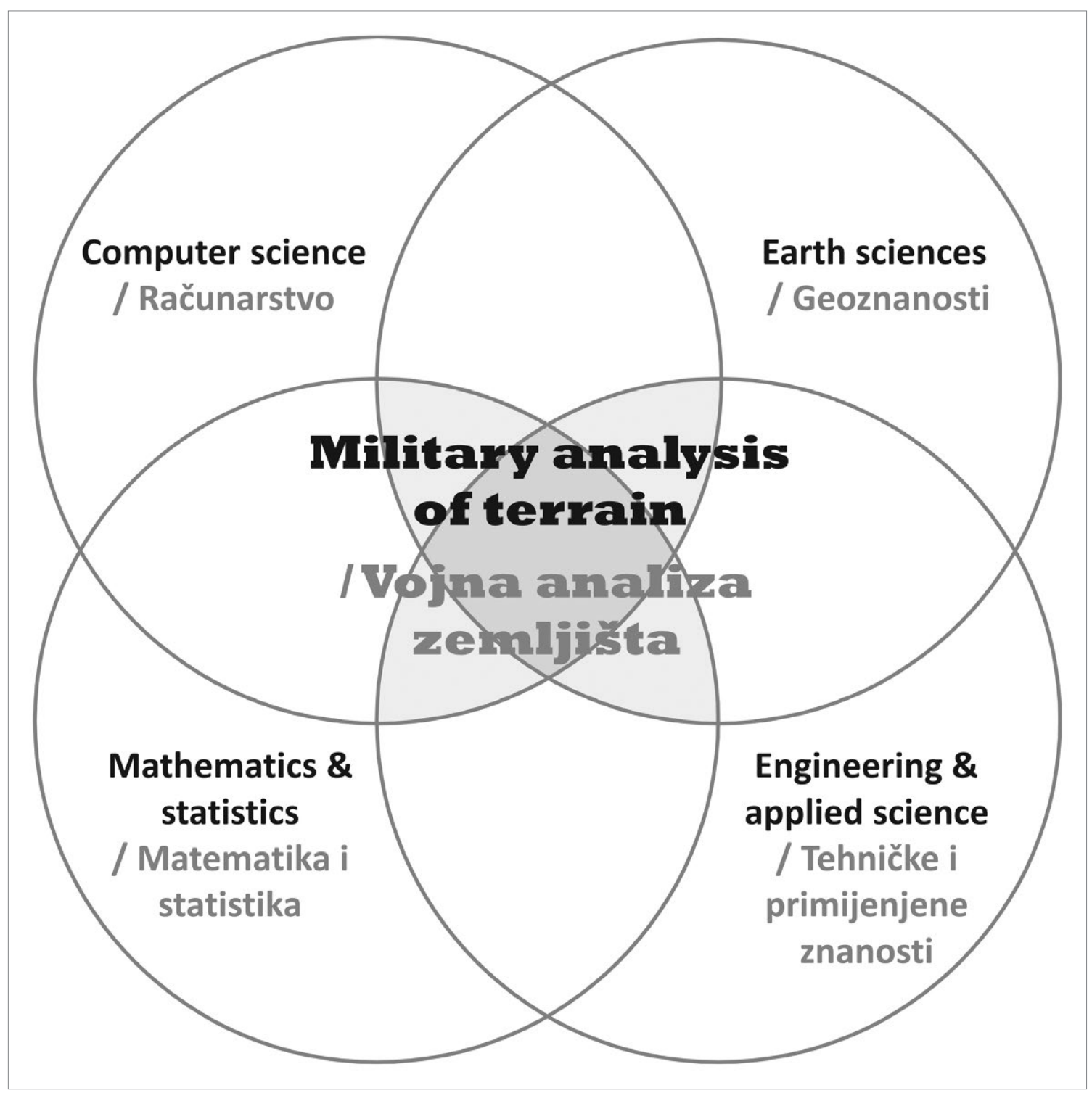

Fig. 1 Position of military analysis of terrain among other sciences

SI. 1. Položaj vojne analize zemljišta unutar ostalih znanosti

Modified according to / Modificirano prema: Pike $(1995,222)$

First World War (Johnson, 1921; Malm, 2018). Numerous military actions, e.g. the Third Battle of Ypres (1917), Battle of Smolensk (1943), or Battle of Monte Cassino (1944), have been determined mainly because of a lack of knowledge about the characteristics of terrain and weather-which, in these cases, rendered vehicles completely unable to manoeuvre. Scientific research of terrain characteristics in terms of vehicle cross-country mobility was originally initiated in the United States of America in 1950 by the Waterways
H Heštera M. Pahernik

Physicalgeographic factors of terrain trafficability of military vehicles according to Western World methodologies

Fizičko-geografski čimbenici terenske prohodnosti vojnih vozila prema metodologijama zapadnoga svijeta tualizirano je tek nakon završetka Prvoga svjetskog rata (Johnson, 1921; Malm, 2018). Brojne vojne akcije, npr. Treća bitka kod Ypresa 1917. godine, bitka kod Smolenska 1943. godine ili bitka kod Monte Casina 1944. godine, okončane su isključivo zbog nepoznavanja obilježja zemljišta i vremenskih prilika i to zbog nemogućnosti pokreta i upotrebe vojne tehnike, odnosno vozila. Znanstvena istraživanja obilježja zemljišta s aspekta terenske prohodnosti vozila prvotno je u Sjedinjenim Američkim 
GEOGRAFSKI

GLASNIK

80/2, 5-31 (2018.)
Experiment Station's (WES). During the 1970s, the analysis of the vehicle terrain trafficability in the U.S. Army became an integral part of the military planning process after the following procedural and doctrinal guides were issued (Bruzese, 1989): Military Geographic Intelligence (Terrain) (1972); Terrain Analysis (1978); and series of Terrain Analysis Procedural Guides (starting in 1979). This was preceded by the development and massive use of a wide range of vehicle types that are currently operational in the armed forces. At the time of writing, vehicle terrain trafficability research is conducted on many levels, from multinational strategic co-operation, to bachelor's theses of university students.

\section{Methodological approaches for physical- geographic factor analysis}

Cross-country vehicle mobility depends on the presence (or lack) of any and all physical-geographic factors and their final mutual interaction (Pearson and Wright, 1980; Earl, 1997; Birkel, 2003; Hofmann et al., 2015). Each of these factors has an effect on vehicle mobility, individually and in interdependence with other factors (Fig. 2).

The greatest research challenge is to determine the final state of terrain trafficability, while keeping a large number of possible interaction combinations among the factors in mind. Using different methodological approaches, authors have established many models in order to define terrain trafficability for vehicles (see section 5).

This review presents investigated factors included in the models, incorporated in the 25 different papers cited in this work. Dependent physical-geographic elements of vehicle terrain trafficability can be divided into five basic groups (Fig. 3). Each of the individual groups contains factors that, depending on their presence and intensity, directly affect a given vehicle's mobility on the terrain. In accordance with the availability of data sources and methodological approaches, authors use different combinations of factors in modelling. Factors are sorted by physical-geographic elements, and the percentage of participation for each factor is expressed within the total number of models covered by the analysis.
Državama (SAD) u 1950-ima započeo Waterways Experiment Station (WES). Tijekom 1970-ih godina analiza prohodnosti zemljišta u vojsci SAD-a postaje sastavni dio procesa planiranja vojnih operacija izdavanjem sljedećih proceduralnih i doktrinarnih vodiča (Bruzese, 1989): Military Geographic Intelligence (Terrain) (1972.), Terrain Analysis (1978.) i serijom Terrain Analysis Procedural Guides (počevši od 1979.). Tomu je prethodio razvitak i masovna upotreba širokoga spektra vozila koja su trenutno u operativnoj uporabi. Danas se istraživanja terenske prohodnosti vozila provode od najviših razina u vidu multinacionalnih suradnja pa sve do razine studentskih završnih radova.

\section{Metodološki pristupi obrade fizičko- geografskih čimbenika}

Terenska pokretljivost vozila ovisi o prisutnosti svakoga pojedinog fizičko-geografskog čimbenika na zemljištu te njihovoj konačnoj međusobnoj interakciji (Pearson i Wright, 1980; Earl, 1997; Birkel, 2003; Hofmann i dr., 2015). Na usporenje vozila svaki od navedenih čimbenika djeluje pojedinačno i u međuovisnosti s ostalim čimbenicima (sl. 2).

Najveći je istraživački izazov utvrđivanje konačnoga stanja prohodnosti zemljišta zbog mnoštva mogućih kombinacija međudjelovanja među čimbenicima. Prilikom definiranja stanja prohodnosti zemljišta autori uspostavljaju brojne modele koristeći se različitim metodološkim osnovama (vidi 5 . poglavlje).

U ovom su radu prikazani istraživani čimbenici kojima se autori koriste u svojim modelima. Fizičko-geografske elemente možemo podijeliti u pet osnovnih skupina o kojima ovisi terenska prohodnost vozila (sl. 3). Svaka od pojedinih skupina u sebi sadržava čimbenike koji ovisno o prisutnosti i intenzitetu izravno utječu na terensku pokretljivost vozila. Sukladno dostupnosti izvora podataka i metodološkim pristupima autori se pri modeliranju služe različitim kombinacijama čimbenika. $\mathrm{Na}$ slici 3 prikazana je analiza čimbenika korištenih u dvadeset pet modela prohodnosti vozila, koje su kreirali autori citirani u ovom radu. Čimbenici su razvrstani po skupinama fizičko-geografskih elemenata te 


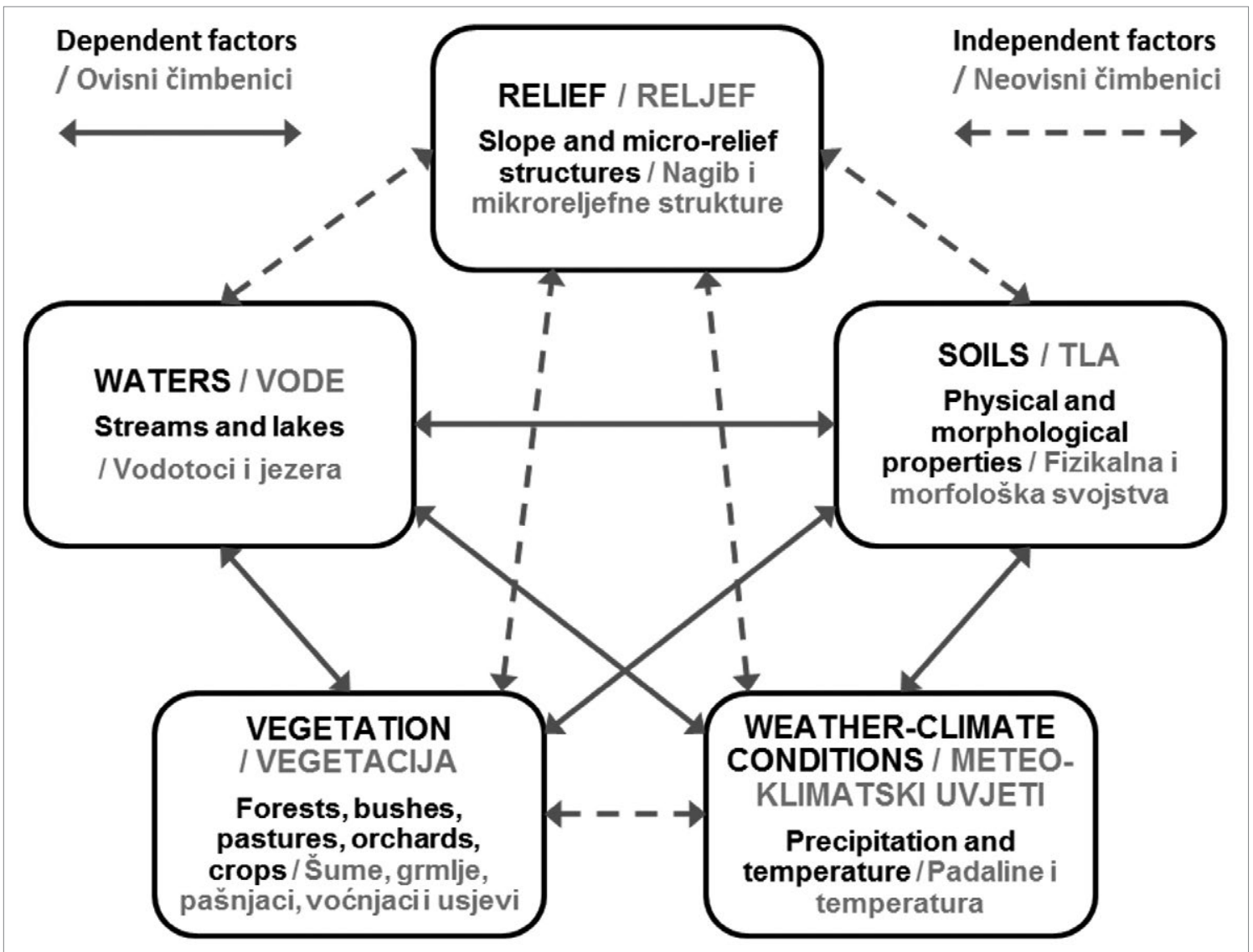

Fig. 2 Mutual relations of basic physical-geographic factors of vehicle terrain trafficability

SI. 2. Međusobni odnosi osnovnih značajki fizičko-geografskih čimbenika terenske prohodnosti vozila

Modified according to / Modificirano prema: Rybansky $(2009,17)$

The fundamental factors that determine vehicle cross-country mobility are mezzo and microrelief forms and structures. The slope of the terrain is a basic morphometric factor and all models have a slope as a parameter in vehicle terrain trafficability models (Fig. 3a). Morphometric parameters of the terrain that directly affect vehicle cross-country mobility are the vertical and lateral slope of terrain (Saarilahti, 2002). Terrain trafficability is related to a given vehicle's ability to overcome the maximum tilt slope, which depends on its technical and tactical characteristics (Pearson and Wright, 1980; Kirkland, 1981; Terrain Analysis, 1990; Ahlvin and Haley, 1992; Donlon and Forbus, 1999; Wong, 2001; Pahernik et al., 2006; Mohtashami et al., 2012; Pimpa, 2012). Slope as a trafficability parameter is indirectly integrated into hydrographic models of soil moisture content predictions, which determine the topograph-
H Heštera

M. Pahernik

Physicalgeographic factors of terrain trafficability of military vehicles according to Western World methodologies

Fizičko-geografski čimbenici terenske prohodnosti vojnih vozila prema metodologijama zapadnoga svijeta je iskazan postotni udio uključenosti pojedinoga čimbenika u ukupnom broju modela obuhvaćenih analizom.

Struktura mezoreljefnih i mikroreljefnih forma temeljni je determinirajući čimbenik pokretljivosti vozila na terenu. Nagib zemljišta je osnovni morfometrijski čimbenik i svaki model sadržava nagib terena kao parametar terenske prohodnosti vozila (sl. 3.a). Morfometrijski parametri zemljišta koji izravno utječu na terensku pokretljivost vozila su vertikalni i bočni nagib zemljišta (Saarilahti, 2002). Prohodnost terena ogleda se u sposobnosti vozila da savlada maksimalni vršni nagib, koji ovisi o tehničko-taktičkim obilježjima svakoga pojedinog vozila (Pearson i Wright, 1980; Kirkland, 1981; Terrain Analysis, 1990; Ahlvin i Haley, 1992; Donlon i Forbus, 1999; Wong, 2001; Pahernik i dr., 2006; Mohtashami i dr., 2012; Pimpa, 2012). Nagib ze- 
GEOGRAFSKI

GLASNIK

80/2, 5-31 (2018.) ic wetness index, and in combination with exposure angle effects on climatic elements. Microrelief surface forms and shapes define the degree of vehicle mobility and terrain trafficability with their deviations (Weiss, 1981; Mintzer and Messmore, 1984; Terrain Analysis, 1990; Shoop, 1993; Murphy and Randolph, 1994; Baylot et al., 2005; Pahernik et al., 2006; Durst et al., 2010; Rybansky et al., 2015). Microrelief forms and phenomena that affect surface roughness include canals, embankments, gullies, ravines, surface rocks, surface stones, and landslides. The common characteristic of all microrelief forms and phenomena is that they do not have a direct impact on the whole vehicle, but on an individual wheel or track unit (Saarilahti, 2002, 44), i.e. ride dynamics (Birkel, 2003; Becker and Els, 2014). Surface roughness indicates the surface irregularity level and is expressed by a root-mean-square value (Jurkat, 1975; Durst et al., 2010; Dawkins, 2011).

The majority of research and modelling has been directed toward exploring geotechnical properties of soils (Production of Cross-Country, 1959). In order to define relations between soil trafficability properties and vehicle mobility, authors use the WES cone index $(\mathrm{CI})$ method, the mean maximum pressure method developed by Rowland (1972), and the bevameter method developed by Bekker (1956) (Ahlvin and Haley, 1992; Wong, 2001; Saarilahti, 2002).

The CI method is the most widespread method because users can make measurements in the field with an easy-to-use hand tool called a cone penetrometer. The mean maximum pressure method also uses a cone penetrometer as a measurement tool, while the bevameter method requires a special vehicle-mounted instrument. A cone penetrometer is used to define the rating cone index (RCI), which is a function of $\mathrm{CI}$ and the remolding index (RI). The soil trafficability evaluation $\mathrm{RCI}$ and the vehicle cone index (VCI) are then compared, whereby vehicle movement on the ground is possible if the VCI value is greater than the RCI value (Ahlvin and Haley, 1992; Wong, 2001). Geotechnical properties of the soil are structured by the Unified Soil Classification System (USCS). The factors that affect vehicle mobility are the soil's shear strength, bearing capacity, tractive forces, slipperiness, and stickiness (Military Geographic Intelligence, 1972). In addition to being mljišta kao parametar posredno je integriran u hidrografske modele predviđanja vlažnosti tla, stoga nagib determinira topografski indeks vlaženja te $u$ kombinaciji s ekspozicijom padine utječe i na klimatske elemente. Mikroreljefne forme na površini svojim devijacijama definiraju stupanj pokretliivosti vozila i prohodnost terena (Weiss, 1981; Mintzer i Messmore, 1984; Terrain Analysis, 1990; Shoop, 1993; Murphy i Randolph, 1994; Baylot i dr., 2005; Pahernik i dr., 2006; Durst i dr., 2010; Rybansky i dr., 2015). Mikroreljefne forme i pojave koje utječu na hrapavost površine su kanali, nasipi, vododerine, jaruge, kamenitost površine, stjenovitost površine i klizišta. „Zajedničko obilježje mikroreljefnih formi i pojava je da ne utječu na vozilo u cjelini, već na svaki kotač ili gusjenicu posebno" (Saarilahti, 2002, 44), odnosno na dinamiku vožnje (Birkel, 2003; Becker i Els, 2014). Hrapavost površine izražava se pomoću kvadratne sredine razlika visine površine (engl. root-mean square) profiliranjem terena (Jurkat, 1975; Durst i dr., 2010; Dawkins, 2011).

Pri modeliranju prohodnosti i istraživanja pojedinačnih čimbenika prohodnosti najviše istraživanja usmjereno je prema geotehničkim svojstvima tla (Production of Cross-Country, 1959). Za definiranje odnosa svojstava prohodnosti tla i mobilnosti vozila autori se koriste WES metodom konusnoga indeksa (KI) (engl. cone index), metodu srednjeg maksimalnog pritiska (engl. mean maximum pressure) koju je razvio Rowland (1972) i metodu bevametra po Bekkeru (1956) (Ahlvin i Haley, 1992; Wong, 2001; Saarilahti, 2002).

Metoda konusnoga indeksa najviše je u upotrebi zbog svoje praktičnost u primjeni na samom terenu jer korisnik može izravno provjeriti prohodnost tla uz pomoć praktičnoga ručnog alata (konusni penetrometar). Metoda srednjega maksimalnog pritiska također se služi konusnim penetrometrom kao alatom, dok metoda bevametra zahtijeva instalaciju posebnoga instrumenta na vozilo. Korištenjem konusnoga penetrometra definira se indeks nosivosti tla (INT) (engl. Rating cone indeks) koji je funkcija KI i remoduliranoga indeksa (RI) (engl. remolding indeks). Zaključno, za evaluaciju prohodnosti tla koristi se usporedba INT-a i konusnoga indeksa vozila (KIV) (engl. vehicle cone index), pri čemu je tlo prohodno ako je vrijednost KIV-a veća 
a) Relief / Reljef

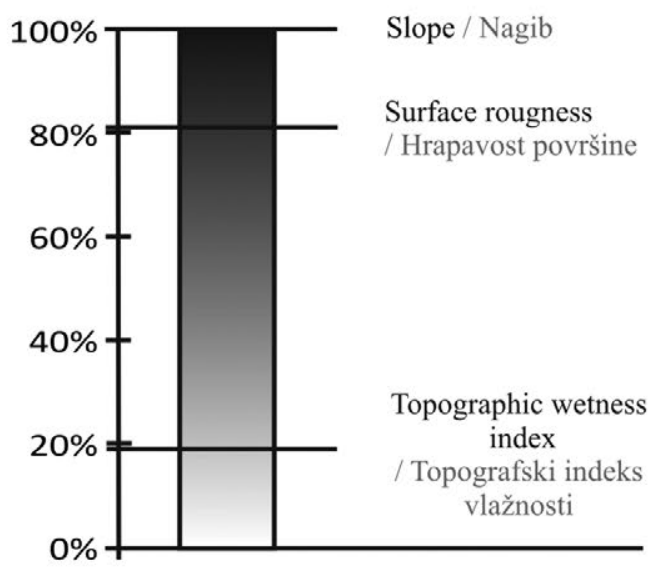

c) Weather-climate / Meteo-klima

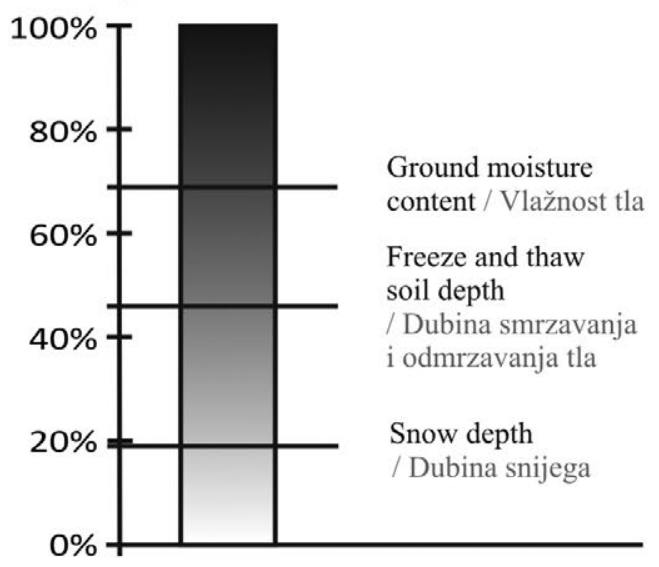

b) Soil / Tlo

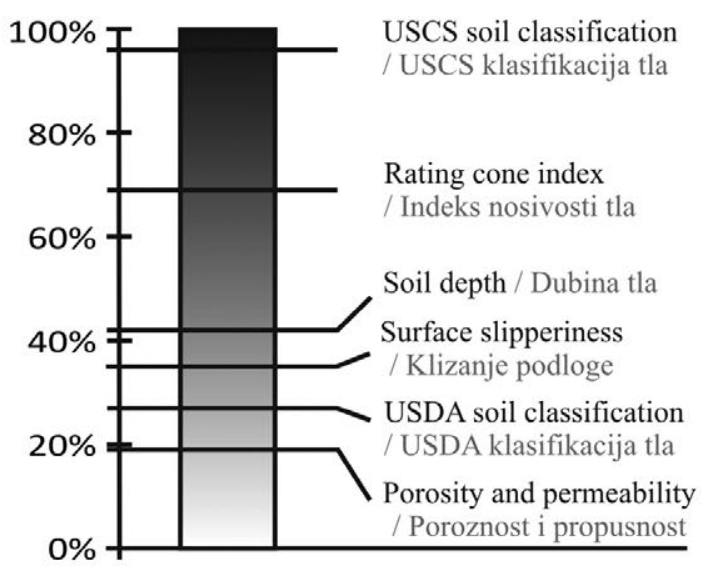

d) Waters / Vode

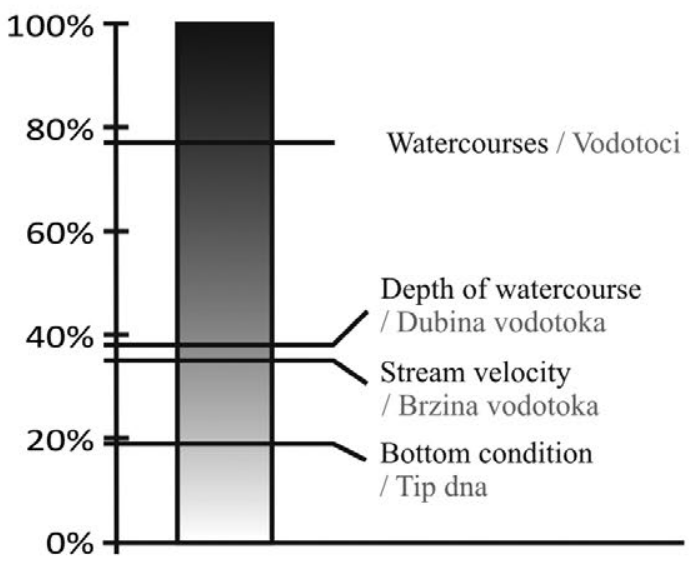

e) Vegetation / Vegetacija

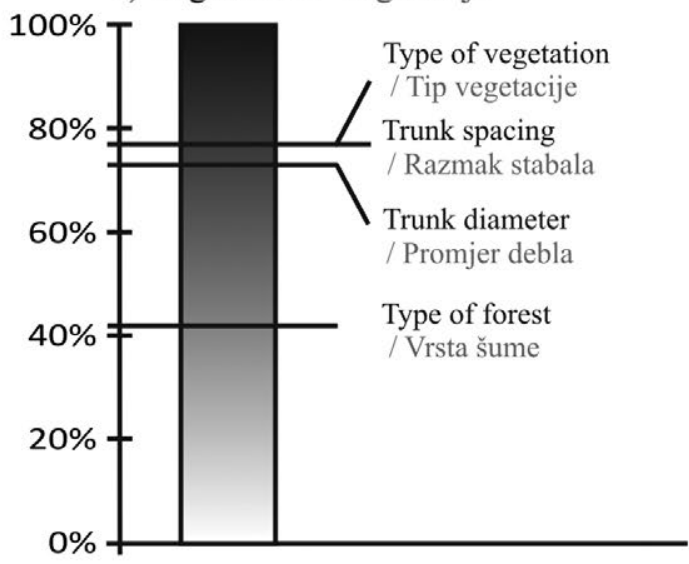

H Heštera

M. Pahernik

Physicalgeographic factors of terrain trafficability of military vehicles according to Western World methodologies

Fizičko-geografski čimbenici terenske prohodnosti vojnih vozila prema metodologijama zapadnoga svijeta

Fig. 3 Percentage of factors included in vehicle terrain trafficability models, structured into the following groups: a) relief; b) soil; c) weather-climate; d) waters; and e) vegetation

SI. 3. Postotni udio uključenih čimbenika u modelima terenske prohodnosti vozila, grupiranih prema fizičko-geografskim elementima: a) reljef, b) Hlo, c) meteo-Kima, d) vode, e) vegetacija 
GEOGRAFSKI

GLASNIK

80/2, 5-31 (2018.) used in the military, USCS classification is used in engineering and geological studies to describe textural, granulometric, and plastic properties of soil (Wright et al., 1981). The problem with this method is that mapping the terrain requires the geotechnical properties of the soil to be tested in a laboratory, and many authors also use the globally-available USDA (U.S. Department of Agriculture) textural classification data in order to define soil types according to the USCS soil classification system. García-Gaines and Frankenstein (2015), Knob (2010), Kourdian (2009) and Wawer et al. (2003) have all stated, however, that the fundamental problem of relating USDA soil classifications to those used in USCS is that there is no direct correlation between the two systems. Furthermore, García-Gaines and Frankenstein (2015) concluded that the previous correlation results obtained on the basis of thousands of soil samples should be regarded with caution.

The load capacity of fine-grained soils is directly related to soil type and moisture content, whereby moisture is a key parameter in soil trafficability determination (Wawer et al., 2003). With the increase of moisture in fine-grained soil, the soil's bearing capacity decreases, and vehicle mobility is reduced. Moisture content directly affects the ability of the ground to withstand vehicle weight and movement, because the moisture defines the state of the soil. Among meteorological phenomena, precipitation and air temperature have the greatest influence on vehicle cross-country mobility, as they directly affect the soil's bearing capacity, freezing point, and moisture level. Vehicle terrain trafficability models contain information of the regarding meteorological phenomena, given after modelling of soil moisture content obtained through structured weather data (Smith and Meyer, 1973; Sullivan et al., 1997; Frankenstein and Koenig, 2004a; 2004b; Frankenstein, 2008). Weather forecasts are only used for short-term (up to 72 hours in advance) predictions of vehicle terrain trafficability, because the accuracy of weather forecasts declines over longer periods. The significance of climatic elements is indirect, and they also indirectly influence other factors of vehicle terrain trafficability. The average number of snowy days, rainfall, and low average temperatures that cause permanently frozen soil such as permafrost depend on these elements. Data od INT-a (Ahlvin i Haley, 1992; Wong, 2001). Geotehnička svojstva tla strukturirana su pomoću jedinstvene klasifikacije tla (engl. Unified Soil Classification System - USCS), a čimbenici koji utječu na pokretljivost vozila su posmična čvrstoća tla, nosivost i vučne sile, klizanje i ljepljivost tla (Military Geographic Intelligence, 1972) Uz vojne USCS klasifikacija koristi se i u inženjerskim i geološkim radovima za opis teksturnih, granulometrijskih i plastičnih svojstava tla (Wright i dr., 1981). Problem ove metode jest $\mathrm{u}$ tome što kartiranje terenske prohodnosti vozila zahtijeva laboratorijska ispitivanja geotehničkih svojstava tla, stoga se mnogi autori služe i globalno dostupnim podatcima USDA (engl. United States Department of Agriculture) teksturalne klasifikacije u svrhu definiranja tipova tla prema USCS klasifikaciji tla. García-Gaines i Frankenstein (2015), Knob (2010), Kourdian (2009) i Wawer i dr. (2003) navode da je osnovni problem transformacije USDA u USCS klase tla u tome što ne postoji izravna korelacija između dvaju sustava. García-Gaines i Frankenstein (2015) zaključuju da dosadašnje rezultate korelacija dobivene temeljem tisuća uzoraka tla treba i dalje uzimati s oprezom.

Nosivost sitnozrnatih tala u izravnoj je korelaciji s tipom tla i udjelom vlažnosti, pri čemu je vlažnost ključan parametar pri utvrđivanju prohodnosti zemljišta (Wawer i dr., 2003). Porastom vlažnosti tla kod sitnozrnatih tala opada nosivost tla, čime se ujedno smanjuje mobilnost vozila. Vlažnost tla izravno utječe na sposobnost tla da podnese težinu i pokret vozila jer vlažnost definira stanje tla. Od meteoroloških pojava najveći utjecaj na terensku mobilnost vozila imaju padaline i temperatura zraka, pri čemu one izravno utječu na nosivost tla, odnosno na zamrzavanje i vlažnost tla. Modeli prohodnosti vozila sadržavaju informacije o meteorološkim pojavama nakon modeliranja stanja vlažnosti tla putem strukturiranih podataka meteoroloških prognoza (Smith i Meyer, 1973; Sullivan i dr. 1997; Frankenstein i Koenig, 2004a; 2004b; Frankenstein, 2008). Meteorološke prognoze koriste se za kratkoročna (do 72 sata unaprijed) predviđanja prohodnosti tla za vozila zbog nemogućnosti točnoga predviđanja vremena za dulja razdoblja. Važnost klimatskih elemenata je indirektna te oni posredno utječu na ostale čimbenike prohodnosti terena jer o 
on climatic elements, in terms of monthly and annual statistical data, is mainly integrated into cartographic products of a larger scale and are directly related to soil type (Hintze, 1991).

Rivers, streams and canals represent linear hydrographic objects that, in most cases, make longitudinal obstruction lines, which have a direct influence on the free movement of vehicles on a given piece of terrain. Research of hydrographic objects includes collection and structuring of information of the morphological properties of banks (including lakes and seas), the speed and depth of watercourses (amphibious vehicles), and the material that forms the bottom of the stream bed (Messmore, 1982; Terrain Analysis; 1990).

The presence of vegetation slows the movement of the vehicle, and forest vegetation can completely disable the movement of all types of vehicles. The main focus of research of forest vegetation includes attributes related to the diameter of the trees at the breast height (1.35 meters) and spacing between trees (Leighty, 1965; Messmore et al., 1981; Shoop, 1993). While modelling vehicle terrain trafficability, the possibility of manoeuvring between the trees is the first determination that must be made. Then, if an excessive density is detected, the possibility of driving over the trees is considered (Haley et al., 1979a; Pearson and Wright, 1980; Messmore et al.,1981; Terrain Analysis, 1990; Ahlvin and Haley, 1992; Mason et al., 2012). Hubacek et al. (2015) also investigated the influence of root systems of different tree species to determine the possibility of tree override.

\section{Data sources and accuracy}

Numerous different spatial data sources and information are used with the intention of predicting terrain trafficability for vehicles. While generating trafficability maps, it is necessary to consider and systematise all the relevant factors in the area of interest. In the past, trafficability maps were made after manually overlaying layers of thematic classes of vehicle movement factors. Before the introduction of GIS technologies, this comprehensive analytical process required highly-qualified analysts with experience in the fields of cartography, topog- njima ovisi prosječan broj snježnih dana u godini, prosječna količina padalina, a niske prosječne temperature uvjetuju trajno smrznuto tlo (permafrost). Podaci o klimatskim elementima, u vidu mjesečnih i godišnjih statističkih podataka, uglavnom su integrirani u kartografske proizvode krupnijih mjerila i u izravnoj su vezi s tipom tla (Hintze, 1991).

Rijeke, potoci i kanali predstavljaju linijske hidrografske objekte koji u većini slučajeva čine izdužene linijske prepreke slobodnom pokretu vozila na zemljištu. Istraživanje vodenih objekata sadržava prikupljanje i strukturiranje podataka o morfološkim obilježjima obale (uključujući jezera i mora), brzini i dubini vodotoka (amfibijska vozila) te sastavnom materijalu koji tvori dno korita tekućice (Messmore, 1982; Terrain Analysis; 1990).

Vegetacija ili biljni pokrov zemljišta svojom prisutnošću usporava pokret vozila, dok šumska vegetacija može i u potpunosti onemogućiti pokret svih vrsta vozila. Osnovni fokus istraživanja šumskoga pokrova obuhvaća atribute vezane uz promjer stabala na prsnoj visini $(1,35 \mathrm{~m})$ i njihov međusobni razmak (Leighty, 1965; Messmore i dr., 1981; Shoop, 1993). Prilikom modeliranja terenske prohodnosti vozila prvotno se razmatra mogućnost manevriranja između stabala, a uslijed prevelike gustoće stabala mogućnost njihova rušenja vozilom (Haley i dr., 1979a; Pearson i Wright, 1980; Messmore i dr., 1981; Terrain Analysis, 1990; Ahlvin i Haley, 1992; Mason i dr., 2012). Hubacek i dr. (2015) istraživali su i utjecaj korijenskoga sustava različitih vrsta drveća na mogućnost rušenja stabala.

\section{Izvori i točnost podataka}

U svrhu predviđanja terenske prohodnosti vozila koriste se brojni i različiti prostorni izvori podataka i informacija. Tijekom kreiranja karte prohodnosti vozila potrebno je razmotriti i sistematizirati sve prisutne čimbenike na prostoru planiranih aktivnosti. Izradi karte prohodnosti prethodilo je ručno preklapanje prethodno načinjenih prozirnica koje su svaka zasebno na sebi sadržavale tematsku cjelinu čimbenika prohodnosti vozila. Prije pojave GIS računalnih sustava ovaj sveobuhvatni analitički proces zahtijevao je visoku kvalificiranost analitičara $\mathrm{i}$ iskustvo iz
H Heštera

M. Pahernik

Physicalgeographic factors of terrain trafficability of military vehicles according to Western World methodologies

Fizičko-geografski čimbenici terenske prohodnosti vojnih vozila prema metodologijama zapadnoga svijeta 
GEOGRAFSKI

GLASNIK

80/2, 5-31 (2018.) raphy, and interpretation of aero-photogrammetric and satellite images. The interpretation of the results required a multidisciplinary team of experts who possessed knowledge of the fields of geodesy, topography, geology, hydrology, soil mechanics, forestry, and ecology (Leighty, 1965; Production of Cross-Country, 1959). Prior to the introduction of computer systems, basic input data were analogue topographic maps, geological maps, pedological maps, and aerial photogrammetric surveys. The development of computing systems in the 1970s replaced this manual process and a new approach was developed, whereby the entire process was integrated into a mathematical model executed on program calculators, using HP-97 and the like (Pearson and Wright, 1980). Present GIS systems and tools provide fast analysis, because they accelerate the processes of preparation, calculation, visualisation, and distribution of large amounts of data, which subsequently contribute to greater reliability and productivity of the entire process (Pimpa et al., 2014). Therefore, it is necessary to study the cross-country movement of vehicles from the aspect of quality of input spatial data. Until the introduction of computer systems and spatial data digitisation, the analogue data sources in use were not very accurate or detailed, considering that the scales of the used map were less than 1:50,000 and scales of aero-photogrammetric images were less than 1:40,000. Maps with a large scale were used for spatial data input (1:50,000 and smaller) and, therefore, the precision and accuracy of the data was very low. There was exceptionally low accuracy in the relief data because the terrain slope information was derived by interpolating the intervals of neighbourhood contour lines, and the whole process was done manually. This made the margin of error in interpretation very high. A major breakthrough in the research of the slope occurred after the development of GIS, due to many available spatial data sources that enabled the production of very accurate and precise digital elevation models (DEM). Today, authors use all available data sources as initial spatial data for structuring and creating spatial databases for further analysis, in order to create information about terrain trafficability for vehicles. Research methodology using applied open source data was performed by Kourdian (2009), who made područja kartografije, topografije i interpretacije aerofotogrametrijskih i satelitskih snimaka. Interpretacija rezultata zahtijevala je multidisciplinarni tim stručnjaka sa znanjem iz područja geodezije, topografije, geologije, hidrologije, mehanike tla, šumarstva i ekologije (Leighty, 1965; Production of Cross-Country, 1959). Prije pojave računalnih sustava osnovni ulazni podaci bile su analogne topografske karte, geološke karte, pedološke karte te aerofotogrametrijske snimke. Razvoj računalnih sustava 1970-ih zamjenjuje ručni proces te se razvija novi pristup u kojem je cjelokupni proces integriran u matematički model koji se izvršava na programskim kalkulatorima, gdje je korišten HP-97 i njemu slični (Pearson i Wright, 1980). Današnji GIS sustavi i alati omogućavaju manji utrošak vremena potrebnog za provedbu analiza na način da ubrzavaju proces pripreme, obrade, analize, vizualizacije i distribucije velike količine podataka koji slijedno tomu doprinose većoj pouzdanosti i produktivnosti cjelokupnoga procesa (Pimpa i dr., 2014). Stoga je potrebno istraživanje terenske prohodnosti vozila promatrati i iz aspekta kvalitete ulaznih prostornih podataka. Do pojave računalnih sustava i digitalizacije prostornih podataka upotrebljavani analogni izvori podataka nisu bili posve točni i detaljni s obzirom na to da su se koristile karte mjerila manjega od 1:50 000 te aerofotogrametrijske snimke mjerila manjega od 1: 40 000. Kao ulazni prostorni podaci koristile su se karte velikoga mjerila (1 : 50000 i manjeg), stoga je i preciznost i točnost podataka bila veoma niska. Podaci o reljefu bili su iznimno niske točnosti jer su informacije o nagibu terena derivirane interpolacijom intervala susjednih izohipsa, a cjelokupni proces rađen je ručno, što je dodatno povećavalo mogućnost pogreške pri interpretaciji. Velik napredak u istraživanju utjecaja nagiba terena nastaje razvojem GIS-a zbog pojave mnoštva izvora prostornih podataka uz pomoć kojih je moguće stvoriti vrlo točne i precizne digitalne modele reljefa (DMR). Trenutno se autori koriste svim dostupnim izvorima podataka, koji služe kao primarni izvori prostornih podataka za strukturiranje i kreiranje prostorne baze podataka za daljnje analize i kreiranje informacija o prohodnosti vozila na željenom području. Metodologijom istraživanja u kojoj su primijenjeni općedostupni open source podaci koristio se Kourdian (2009). Napravio je sintezu multispektralnih podataka dobivenih radarom sa 
a synthesis of multispectral data obtained via synthetic aperture radar (SAR) and open source data, combining remote sensing and GIS to create structured layers of trafficability factors. The same approach in which terrain trafficability studies were carried out entirely with remote sensing data was presented by Bacon et al. (2008), Kruse et al. (2000), and Sadiya et al. (2017). Campbell (2012), Dawkins (2011), Gustafsson and Hägerstrand (2005), Kirkland (1981), Kristalova (2015), Mohamad Rabab (2002), Mohtashami et al. (2012) and Rybansky et al. (2015) used high resolution satellite images and Light Detection and Ranging (LIDAR) recordings in order to implement high accuracy and precision data in their research, which gave DMR and vegetation cover data greater accuracy (Andersen et al., 2003). It should be emphasised that remote sensing data analysis cannot achieve complete detail and reliability in terms of data (Leighty, 1965; Kruse et al., 2000; Wawer et al., 2003), and vegetation and soil data cannot be collected without direct verification in the field (Laskey et al., 2010). Other authors have used the results of remote sensing mostly as secondary sources of information, increasing the credibility of a data source obtained from laboratory analysis or measurements taken on the ground. The presence of detailed spatial data of an area depends primarily on world organisations and state institutions, which are also the most common contracting authorities and owners of geospatial data for a given area.

Hoškova-Mayerova et al. (2010), Laskey et al. (2010), and Kristalova (2015) emphasised that knowledge about the quality of input spatial data is crucial in order to determine the probability of result deviations in terrain trafficability modelling. They also stressed that the entire process of data quality control should be systematised and that it should include assessment and quality description stored in metadata. Waldock and Corne (2011) have explored the possibility of cross-country vehicle movement prediction on unstructured open source spatial data using multi-criteria optimisation. Horttanainen and Virrantaus (2004) concluded that uncertainty in data accuracy should be noted throughout the modelling process, and the final user, as the decision maker, should be informed of the level of data inaccuracy. sintetičkom antenom i open source podataka, gdje je uz pomoć daljinskih istraživanja i GIS-a čimbenike strukturirao u slojeve prohodnosti vozila. Identičan pristup u kojem su istraživanje terenske prohodnosti proveli isključivo uz pomoć daljinskih istraživanja prikazali su i Bacon i dr. (2008), Kruse i dr. (2000) i Sadiya i dr. (2017). Korištenjem satelitskih snimaka visoke rezolucije i LIDAR (engl. Light Detection and Ranging) snimaka u istraživanjima Campbell (2012), Dawkins (2011), Gustafsson i Hägerstrand (2005), Kirkland (1981), Kristalova (2015), Mohamad Rabab (2002), Mohtashami i dr. (2012) i Rybansky i dr. (2015) implementirali su podatke visoke točnosti i preciznosti, čija je upotreba doprinijela većoj točnosti podataka DMR-a i vegetacijskoga pokrova zemljišta (Andersen i dr., 2003). Potrebno je naglasiti da se daljinskim istraživanjima ne može postići detaljnost i potpuna pouzdanost podataka (Leighty, 1965; Kruse i dr. 2000; Wawer i dr., 2003), dok podatke o vegetaciji i pedološkim svojstvima tla nije moguće prikupiti bez izravne provjere na samom terenu (Laskey i dr., 2010). Rezultate daljinskih istraživanja ostali autori koriste većinom kao sekundarne izvore podataka, pri čemu oni doprinose vjerodostojnosti izvornih podataka koji su dobiveni laboratorijskim analizama ili mjerenjima na terenu. Prisutnost detaljnih prostornih podataka nekoga područja ovisi ponajprije o svjetskim organizacijama i državnim institucijama koje su ujedno najčešći naručitelji i vlasnici geoprostornih podataka za konkretno područje.

Hoškova-Mayerova i dr. (2010), Laskey i dr. (2010) i Kristalova (2015) posebice naglašavaju da je poznavanje kvalitete ulaznih prostornih podataka ključno kako bi se mogla utvrditi vjerojatnost odstupanja rezultata prilikom modeliranja terenske prohodnosti. Naglašavaju da cjelokupni proces kontrole kvalitete podataka treba sistematizirati te da on treba sadržavati procjenu i opis kvalitete kroz metapodatke. Waldock i Corne (2011) istražili su mogućnosti predviđanja terenske prohodnosti vozila na nestrukturiranim open source prostornim podacima koristeći se metodom višekriterijske optimizacije. Horttanainen i Virrantaus (2004) zaključuju da nesigurnost $\mathrm{u}$ točnosti podataka treba biti sadržana u cijelom procesu modeliranja te krajnjega korisnika kao donositelja odluka treba upoznati s razinom netočnosti podataka.
H Heštera

M. Pahernik

Physicalgeographic factors of terrain trafficability of military vehicles according to Western World methodologies

Fizičko-geografski čimbenici terenske prohodnosti vojnih vozila prema metodologijama zapadnoga svijeta 
GEOGRAFSKI

GLASNIK

80/2,5-31 (2018.)

\section{Modelling/structuring of physical-geographic factors of terrain trafficability for military vehicles}

Modelling of vehicle terrain trafficability started in the 1970s and 1980s in the U.S. Army. All models of vehicle terrain trafficability want to reproduce (in different ways) how overall ground elements slow down the vehicle in relation to its maximum predicted speed (Ahlvin and Haley, 1992). The Heuristic Approach (Waldock and Corne, 2011) of trafficability modelling based on the dynamic mathematical models of the Army Material Command Mobility Model (AMC) and the NATO Reference Mobility Model (NRMM) (Hohmann et al., 2013) were limited by their many input parameters and a multitude mathematical formulas, which made it more difficult for the end users. The invention and development of new computer technologies in the late 1980s enabled implementation of mathematical models into GIS. At that time, computer technology was still not developed enough to generate processing, calculations, and visualisation of spatial data at a scale higher than the local level (Loomer, 1987). In contrast to mathematically-oriented models such as NRMM, models with a stochastic approach emerged (Lessem et al., 1992). Birkel (2003) recommended revision of models used for military purposes by analysing the potential development of Modular Semi-Automated Forces (MoDSAF), Close Combat Tactical Trainer (CCTT), Warfighter's Simulation (WARSIM), NRMM I, and NRMM II (Hohmann et al., 2013). Their main purpose is to train drivers using computer simulations representing a virtual reality of possible situations on the ground (Affleck et al., 2009). The analysis, data quality control, and modelling of terrain trafficability factors based on probabilistic and statistical theories using the Bayesian theorem were applied in the work of Laskey et al. (2010). Modelling using fuzzy logic in models and analysis of terrain trafficability was applied by Atkinson et al. (2005), George et al. (2017), Hofmann et al. (2013; 2015), Slocum (2003), Talhofer et al. (2015) in raster analysis, where simple Boolean logic $^{4}$ was upgraded using the set theory. Gustafsson and Hägerstrand (2005) applied a special approach

\footnotetext{
4 Boolean algebra is a part of mathematical logic where the values of the variables are defined by logical operators "true" and "false", which are usually indicated by values 1 and 0 .
}

Modeliranje/strukłuriranje fizičko-geografskih čimbenika terenske prohodnosti vojnih vozila

Modeliranje terenske prohodnosti vozila započelo je 1970-ih i 1980-ih godina u vojsci SAD-a. Svi modeli terenske prohodnosti vozila na različite načine žele prikazati u kojoj mjeri sveukupne pojave na zemljištu usporavaju vozilo u odnosu na maksimalnu predviđenu brzinu kretanja vozila (Ahlvin i Haley, 1992). Heuristički pristup (Waldock i Corne, 2011) modeliranja prohodnosti baziran na dinamičkim matematičkim modelima Army Material Command Mobility Model (AMC) i NATO Reference Mobility Model (NRMM) (Hohmann i dr., 2013) bio je ograničen sa svojim brojnim ulaznim parametrima i mnoštvom matematičkih formulacija, što je otežavalo upotrebu kod krajnjih korisnika. Pojavom i razvojem računalnih tehnologija krajem 1980-ih godina stvorila se mogućnost implementacije matematičkih modela u GIS sustav. Računalna tehnologija tada još nije bila na dovoljnoj razini razvoja te i dalje nije omogućavala obradu, izračune i vizualizaciju prostornih podataka na mjerilu većem od lokalne razine (Loomer, 1987). Nasuprot matematički orijentiranim modelima, kao što je NRMM, pojavili su se i modeli sa stohastičkim pristupom (Lessem i dr., 1992). Birkel (2003) preporučuje reviziju modela korištenih u vojne svrhe gdje je analizirao mogući razvojni potencijal Modular Semi-Automated Forces (MoDSAF), Close Combat Tactical Trainer (CCTT), Warfightering Simulation (WARSIM), NRMM I i NRMM II (Hohmann i dr., 2013). Njihova je osnovna namjena osposobljavanje vozača uz pomoć računalnih simulacija kako bi se stvorila što vjernija slika stvarnosti (Affleck i dr., 2009). Analizu, kvalitetu podataka i modeliranje čimbenika terenske prohodnosti zasnovanu na probabilističkim i statističkim teorijama koristeći se Bayesovim teoremom primijenili su u svom radu Laskey i dr. (2010). Modeliranje uz neizrazitu (engl. fuzzy) logiku pri modeliranju i analizi čimbenika terenske prohodnosti primjenjuju Atkinson i dr. (2005), George i dr. (2017), Hofmann i dr. (2013; 2015), Slocum (2003), Talhofer i dr. (2015), gdje je nadograđena jednostavna Booleova logika ${ }^{4}$ primjenom teorije skupova u rasterskoj analizi. Po-

\footnotetext{
4 Booleova algebra je dio matematičke logike u kojoj su vrijednosti varijabli definirane logičkim operatorima „istina” i „laž”, koji se obično označavaju vrijednostima 1 i 0 .
} 
based on the graph theory and vector analysis based on the network data model. As a part of the ECORS ${ }^{5}$ project, Grandjean et al. (2009) and Hohmann et al. (2013) developed a model that included mechanical and tactical properties of the vehicles, mathematical and physical theories, and the results of empirical research. The model has been transformed into a spatial decision support system (SDSS) that provides the end user with the opportunity to customise cartographic products according to their requirements (Densham 1991; Lubello, 2008). Since the late 1990s, authors have enjoyed the multi-functional nature of GIS, which integrated and unified all organisational processes, i.e. structuring, modelling, processing, analysis, evaluation, and visualisation. Consequently, GIS has become the basic tool for terrain trafficability determination. The ArcGIS platform has been used by Eichordt (2003), Handke and Butikofer (1994), Pahernik et al. (2006), Pimpa (2012), Sadiya et al. (2017) and Vrščaj and Godeša (2010), and its visual programming language Model Builder for formulation and programing was used by Grogan (2009), Hofmann et al. (2015), Hohmann et al. (2013), Lubello (2008), Mohtashami et al. (2012). Of course, GIS is not the only method in modelling and spatial analysis, many other mathematical models, statistical programs, meteorological models and hydrological models are also in use (Gumoś, 2005). $\mathrm{FASST}^{6}, \mathrm{SMSP}^{7}$ and $\mathrm{SOFT}^{8}$ models have been developed as a result of continuous research and implementation of complex algorithms. These models simulate dynamic processes on the ground based on meteorological conditions. Furthermore, they simulate hydro-geomorphological processes to determine soil moisture fluctuation, i.e. predicting soil moisture content based on available data (Albert et al., 2000; Frankenstein and Koenig, 2004b; Mason et al., 2003).

Some authors have performed model validation on the ground (Hohmann et al., 2013) and this remains the only credible testing method of model accuracy and reliability. Accordingly, Lessem et

\footnotetext{
5 Etude Continentale et Océanique par Réflexion et Réfraction Sismiques

6 Fast All-season Soil STrength

7 Soil moisture-strength prediction

8 Short Term Operational Forecasts of Trafficability
}

seban pristup baziran na teoriji grafova $\mathrm{i}$ isključivo vektorskoj analizi organiziranoj na osnovi mrežnoga modela podataka primijenili su Gustafsson i Hägerstrand (2005). Grandjean i dr. (2009) i Hohmann i dr. (2013) u sklopu projekta ECORS ${ }^{5}$ razvijaju model koji uključuje mehanička i taktička obilježja vozila, matematičke i fizičke zakonitosti i rezultate empirijskih istraživanja. Model je pretočen u svojevrsni sustav za pomoć pri prostornom odlučivanju koji pruža krajnjemu korisniku mogućnost prilagodbe izlaznih kartografskih proizvoda prema njegovim potrebama (Densham, 1991; Lubello, 2008). Od kraja 1990-ih autori se počinju koristiti multifunkcionalnim obilježjima GIS-a unutar kojega su integrirani i objedinjeni svi potrebni procesi organizacije, strukturiranja, modeliranja, procesiranja, analize, evaluacije i vizualizacije terenske prohodnosti vozila. GIS je na taj način postao osnovni alat za utvrđivanje terenske prohodnosti vozila. ArcGIS platformom koriste se Eichordt (2003), Handke i Butikofer (1994), Pahernik i dr. (2006), Pimpa (2012), Sadiya i dr. (2017) i Vrščaj i Godeša (2010), a modulom Model Builder za formuliranje i programiranje procesa koriste se Grogan (2009), Hofmann i dr. (2015), Hohmann i dr. (2013), Lubello (2008), Mohtashami i dr. (2012). GIS svakako nije jedina korištena metoda pri modeliranju i prostornoj analizi, stoga se koriste matematički modeli, statistički programi, meteorološki modeli i hidrološki modeli (Gumoś, 2005). Kao rezultat kontinuiranih istraživanja upotrebom složenih algoritama razvijeni su modeli FASST, ${ }^{6} \mathrm{SMSP}^{7}$ i SOFT ${ }^{8}$ kojima je glavni cilj ustvrditi dinamičke procese koji se odvijaju na zemljištu, a uvjetovani su meteorološkim prilikama. Modeli simuliraju hidrogeomorfološke procese kako bi se utvrdila fluktuacija vlažnosti u tlu, odnosno predvidjela razina vlažnosti tla temeljem poznatih podataka (Albert i dr. 2000; Frankenstein i Koenig, 2004b; Mason i dr., 2003).

Nakon izrađenoga modela i provedenih računalnih kalkulacija neki su autori proveli i empirijska istraživanja točnosti modela na samom terenu u stvarnim situacijama (Hohmann i dr., 2013), a to je ujedno i

\footnotetext{
5 Etude Continentale et Océanique par Réflexion et Réfraction Sismiques

6 Fast All-season Soil STrength

7 Soil moisture-strength prediction

8 Short Term Operational Forecasts of Trafficability
}

H Heštera M. Pahernik

Physicalgeographic factors of terrain trafficability of military vehicles according to Western World methodologies

Fizičko-geografski čimbenici terenske prohodnosti vojnih vozila prema metodologijama zapadnoga svijeta 
HRVATSKI

GEOGRAFSKI

GLASNIK

80/2, 5-31 (2018.) al. (1992), Li et al. (2007), Murphy and Randolph (1994), Rybansky et al. (2015) and Talhofer et al. (2015) have all tested their models on the ground using GPS receivers. The authors have used results implemented using the NRMM model as the most frequent and most commonly applied parameters in calculations within their models. The NRMM model is a combination of empirical research and theoretical predictions, and the parameters defined in this model are derived from several decades of systematic tests and result validation (List of Publications, 1993). Model testing is carried out in such a way that a predefined route calculates the model, and then the same vehicle passes the route under real conditions. The general conclusions of the test are related to the statistical significance of result deviations predicted by the model. Determination of deviation causes is the most complex and time-consuming, because it is very difficult to isolate each factor separately, due to factor interdependence (see Fig. 2). Final results are highly dependent on drivers, because their experience and driving habits generate deviations and affect the accuracy of the test driving results (Talhofer et al., 2015).

\section{Interpretation of terrain trafficability results for military vehicles}

The geographic map is the focal point of the military decision-making process and it provides a great deal of information. The target product of every military analysis of a terrain is a thematic map of vehicle trafficability. The vehicle terrain trafficability map is a kind of synthesis of factor interactions that are present in the area. The maps generally contain three categories of vehicle trafficability and describe the terrain as GO, SLOW GO and NO GO areas (Pearson and Wright, 1980; Wynn, 1985; Terrain Analysis, 1990; Grogan, 2009; Kourdian, 2009; Hohmann et al., 2013; Pimpa et al., 2014; Rybansky et al., 2015; Sadiya et al., 2017). The purpose of thematic cartographic products and interactive applications is to support a decision-making process in many activities (Hohmann et al., 2013; Kourdian, 2009). The thematic trafficability map provides military decision-making personnel a better un- jedina vjerodostojna metoda provjere točnosti i pouzdanosti modela. Stoga su Lessem i dr. (1992), Li i dr. (2007), Murphy i Randolph (1994), Rybansky i dr. (2015) i Talhofer i dr. (2015) svoje modele testirali na terenu služeći se GPS prijamnicima. Najprimjenjivaniji i najčešće korišteni parametri pri kalkulacijama unutar svojih modela autori koriste rezultate implementirane u NRMM modelu. NRMM model je kombinacija empirijskih istraživanja i teorijskih predviđanja, a parametri definirani u ovom modelu rezultat su više desetljeća sustavnoga testiranja i primjene dobivenih rezultata (List of Publications, 1993). Testiranja modela provode se na način da unaprijed definiranu rutu izračuna model, a potom po istoj ruti prolazi vozilo u stvarnim uvjetima. Općeniti zaključci testiranja odnosne se na statističku značajnost odstupanja stvarnih rezultata nasuprot modelom predviđenih rezultata. Proces utvrđivanja uzroka odstupanja je najkompleksniji i najdugotrajniji jer je vrlo teško izolirati svaki čimbenik zasebno zbog njihove međuovisnosti (vidi sliku 2). Krajnji rezultati iznimno ovise i o vozačima jer oni svojim iskustvom, načinom vožnje i poznavanjem prostora testiranja generiraju odstupanja i definiraju točnost rezultata testnih vožnja (Talhofer i dr., 2015).

\section{Interpretacija rezultata terenske prohodnosti vojnih vozila}

Geografska karta žarišna je točka procesa donošenja vojnih odluka. Ona pruža najviše informacija. Ciljani je proizvod svake vojne analize zemljišta tematska karta prohodnosti vozila. Karta terenske prohodnosti vozila je svojevrsna sinteza interakcije svih čimbenika koji su prisutni u prostoru. Karte općenito sadržavaju tri kategorije prohodnosti vozila i opisuju teren kao prohodan, teško prohodan ili neprohodan (Pearson and Wright, 1980; Wynn, 1985; Terrain Analysis, 1990; Grogan, 2009; Kourdian, 2009; Hohmann et al., 2013; Pimpa et al., 2014; Rybansky et al., 2015; Sadiya et al., 2017). Svrha izrade tematskih kartografskih proizvoda i interaktivnih aplikacija jest pomoć pri kvalitetnijem donošenju odluka za provedbu širokoga spektra aktivnosti (Hohmann i dr., 2013; Kourdian, 2009). Tematska karta prohodnosti donositeljima vojnih odluka doprinosi boljemu razumijevanju zemljišta, temeljem koje korisnik bira vrstu i veličinu postrojbe s 

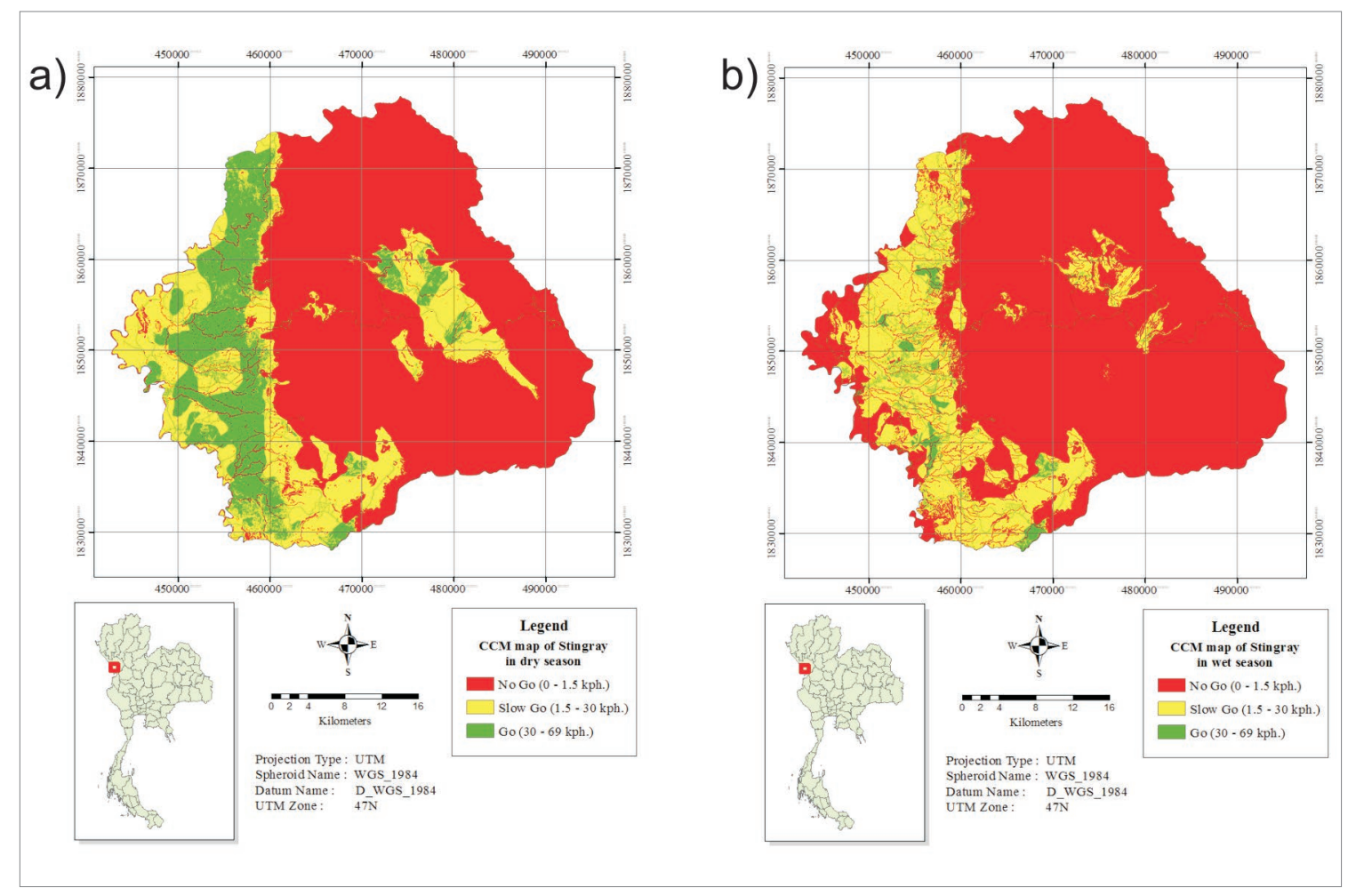

H Heštera

M. Pahernik

Fig. 4 Example of CCM map for tank cavalry (Stingray) in a) dry season and b) wet season

SI. 4. Primjer karte terenske mobilnosti tenka (Stingray) $\cup$ a) sušnom periodu $i$ b) kišnom periodu

Source/ Izvor: Pimpa $(2012,118-119)$

derstanding of the terrain, so they can choose type and size of the unit for a specific mission (Military Geographic Intelligence, 1972; Pearson and Wright, 1980). It is common practice in all climate regions to make multiple versions of trafficability maps, based upon large precipitation amplitudes and the change of seasons (Baylot et al., 2005; Affleck et al., 2009; Pimpa, 2012). Trafficability maps for winter distinguish areas with frozen state ofground, those for summer distinguish dry areas, and those for autumn and spring distinguish wet areas (Schreier and Lavkulich, 1978). The dependence on dynamic factors is presented in cartographic form with two scenarios for wet and dry states of the ground, i.e. in dry and wet seasons (Fig. 4).

The final cartographic product that represents a terrain trafficability map for vehicles is the result of collecting, structuring, evaluation, modelling, standardisation, and generalisation of spatial data. Each of these processes in models generates a certain degree of error, and each step increases the probability kojom će provesti aktivnosti na terenu (Military Geographic Intelligence, 1972; Pearson i Wright, 1980). Uobičajena je praksa za sve geografske širine da se na temelju velike razlike u količini padalina i razlikama u temperaturama kroz godinu, odnosno snježnim ili kišnim i sušnim periodima, napravi više verzija karata prohodnosti (Baylot i dr., 2005; Affleck i dr., 2009; Pimpa, 2012). Karte prohodnosti prema godišnjim dobima prikazuju zimski period sa zaleđenim stanjem površine tla, ljetni period u sušnom razdoblju te vlažne periode u proljeće i jesen (Schreier i Lavkulich, 1978). Zavisnost o dinamičkim čimbenicima u kartografskom obliku prikazuju se u obliku dvaju scenarija, za mokro i suho stanje podloge, odnosno nakon obilnih padalina i bez padalina (sl. 4).

Krajnji kartografski proizvod koji predstavlja kartu terenske prohodnosti vozila plod je procesa prikupljanja, strukturiranja, evaluacije, modeliranja, standardizacije i generalizacije prostornih podataka. Svaki od navedenih procesa u sebi generira određeni stupanj pogreške, odnosno svakim korakom
Physicalgeographic factors of terrain trafficability of military vehicles according to Western World methodologies

Fizičko-geografski čimbenici terenske prohodnosti vojnih vozila prema metodologijama zapadnoga svijeta 
HRVATSKI

GEOGRAFSKI

GLASNIK

$80 / 2,5-31(2018$.

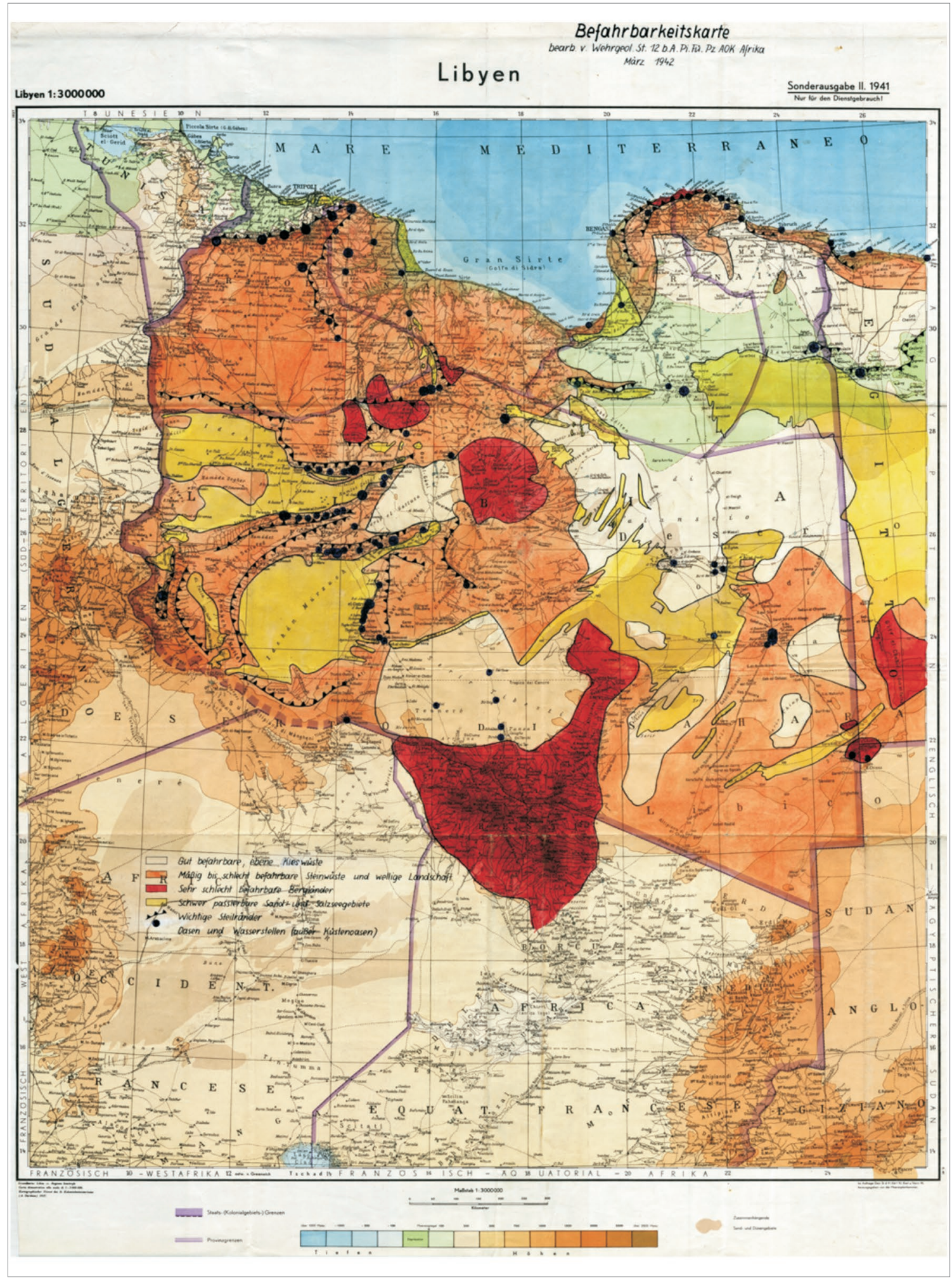

Fig. 5 Example of trafficability map for strategic decision-making level, German trafficability map of Libya (1941).

SI. 5. Primjer karte prohodnosti vozila na strateškoj razini odlučivanja. Njemačka karta prohodnosti vozila za područje Libije (1941).

Source / Izvor: Kuckelkorn (1942) 
of prediction error. In accordance with necessary details and quality of input data, from which models derive accuracy (Lessem et al., 1992; Grogan, 2009; Laskey et al., 2010), there are several types of cartographic products of different scales. Hohmann et al. $(2013,90)$ stated: When the thematic cartographic product is made with the purpose of displaying vehicle terrain trafficability, it is necessary to take into account the purpose and necessity of accuracy in space and time. Therefore, we can categorize vehicle trafficability maps directed onto three levels of military decision-making and operations:

- Strategic or regional level: decisions are made several months in advance, maps have a small scale and meteorological changes are planned based on the change of the seasons (example Fig. 5);

- Operational or medium level: decisions are made several weeks in advance, the maps have a medium scale, and the meteorological changes are planned monthly (example Fig. 6);

- Tactical or local level: decisions are made several days in advance, maps have large to medium scale, and meteorological changes are planned upon weather forecasts (example Fig. 7).

Thematic maps of terrain trafficability provide general information of the area they display. To plan the movement of a large number of vehicles through a given area, a wide space that is in accordance with the size of moving troops is necessary (Intelligence preparation, 1994). Based on the algorithms and generated GIS layers we can distinguish the areas of possible vehicle movement, i.e. avenues of approach and mobility corridors (Laskey et al., 2010; Pimpa, 2012). The planning and selection of a final movement route are ultimately left to the decision maker. With the interactive GIS system, it is possible to plan a vehicle movement route by selecting the start and end points of a route. Unlike road trip planners that are based on quantitative methods using existing road networks (vector data format), the planning of a vehicle movement path on open terrain is more complex (Donlon and Forbus, 1999). The complexity of the problem is greater, because of the many factors included in the calculation process of the movement path. For calculation of the most povećava se vjerojatnost pogreške modela. U skladu s potrebnom detaljnosti i kvalitetom ulaznih podataka, koji deriviraju i samu točnost modela (Lessem i dr., 1992; Grogan, 2009; Laskey i dr., 2010), postoji i nekoliko vrsta izlaznih kartografskih proizvoda različitih mjerila. Hohmann i dr. $(2013,90)$ navode: Prilikom stvaranja tematskih kartografskih proizvoda sa svrhom prikaza terenske prohodnosti vozila treba imati u vidu namjenu i potrebnu točnost $\mathrm{u}$ prostoru i vremenu, stoga možemo karte prohodnosti vozila kategorizirati prema tri razine vojnoga odlučivanja i provedbe operacija:

- Strategijska ili regionalna razina: odluke se donose nekoliko mjeseci unaprijed, karte su sitnoga mjerila i meteorološke promjene planiraju se na osnovi promjena godišnjih doba (primjer sl. 5)

- Operativna ili srednja razina: odluke se donose nekoliko tjedana unaprijed, karte su srednjega mjerila, analize meteoroloških promjena planiraju se na mjesečnoj razini (primjer sl.6)

- Taktička ili lokalna razina: odluke se donose nekoliko dana unaprijed, karte su krupnoga do srednjega mjerila, analize meteoroloških promjena planiraju se na temelju vremenskih prognoza (primjer sl. 7).

Tematske karte terenske prohodnosti vozila pružaju općenitu informaciju za široki prostor koji prikazuju. Za planiranje mogućega pokreta većega broja vozila kroz određeno područje potreban je široki prostor koji je u skladu s veličinom snaga kojom se želi kroz njega proći (Intelligence preparation, 1994). Temeljem algoritama i računalno generiranih GIS podloga moguće je kreirati uska i ograničena područja prohodna za veći broj vozila, odnosno avenije i koridore mobilnosti vozila (Laskey i dr., 2010; Pimpa, 2012). Planiranje i odabir konkretne rute kretanja prepuštena je donositelju odluka. Interaktivni GIS sustavi omogućuju planiranje rute kretanja vozila odabirom polazišne i završne točke kretanja. Za razliku od cestovnoga planera putovanja koji je zasnovan na kvantitativnim metodama na postojećoj mreži prometnica (vektorski oblik podataka), planiranje rute kretanja vozila u terenskim uvjetima mnogo je kompleksnije (Donlon i Forbus, 1999). Usloženost problema veća je zbog brojnih čimbenika koji su dionici procesa kalkulacije rute kretanja. Al-Hasan
H Heštera

M. Pahernik

Physicalgeographic factors of terrain trafficability of military vehicles according to Western World methodologies

Fizičko-geografski čimbenici terenske prohodnosti vojnih vozila prema metodologijama zapadnoga svijeta 
HRVATSKI

GEOGRAFSKI

GLASNIK

80/2, 5-31 (2018.) optimal, fastest, or shortest path in raster data format in GIS, Al-Hasan and Vachtsevanos (2002), Suvinen et al. (2003), Tarapata (2003), Atkinson et al. (2005), Gumoś (2005), Lantz et al. (2005), Pahernik et al. (2006), Suvinen (2006), Grandjean et al. (2009), Prato (2009), Laskey et al. (2010), Campbell (2012), Mohtashami et al. (2012), Rybansky (2014), Hofmann et al. (2015), Rybansky et al. (2015) and Talhofer et al. (2015) used the costpath function. A path calculation methodology based on graph theories, which also used Dijkstra and $A^{*}$ algorithms, was investigated by Gustafs- i Vachtsevanos (2002), Suvinen i dr. (2003), Tarapata (2003), Atkinson i dr. (2005), Gumoś (2005), Lantz i dr. (2005), Pahernik i dr. (2006), Suvinen (2006), Grandjean i dr. (2009), Prato (2009), Laskey i dr. (2010), Campbell (2012), Mohtashami i dr. (2012), Rybansky (2014), Hofmann i dr. (2015), Rybansky i dr. (2015) i Talhofer i dr. (2015) za izračune optimalne, najbrže ili najkraće rute kretanja u rasterskom formatu podataka u računalnim i GIS sustavima koriste costpath funkciju. Metodologiju izračuna rute kretanja zasnovanu na teoriji grafova, koja također koristi Dijkstra i A*algoritme istražili

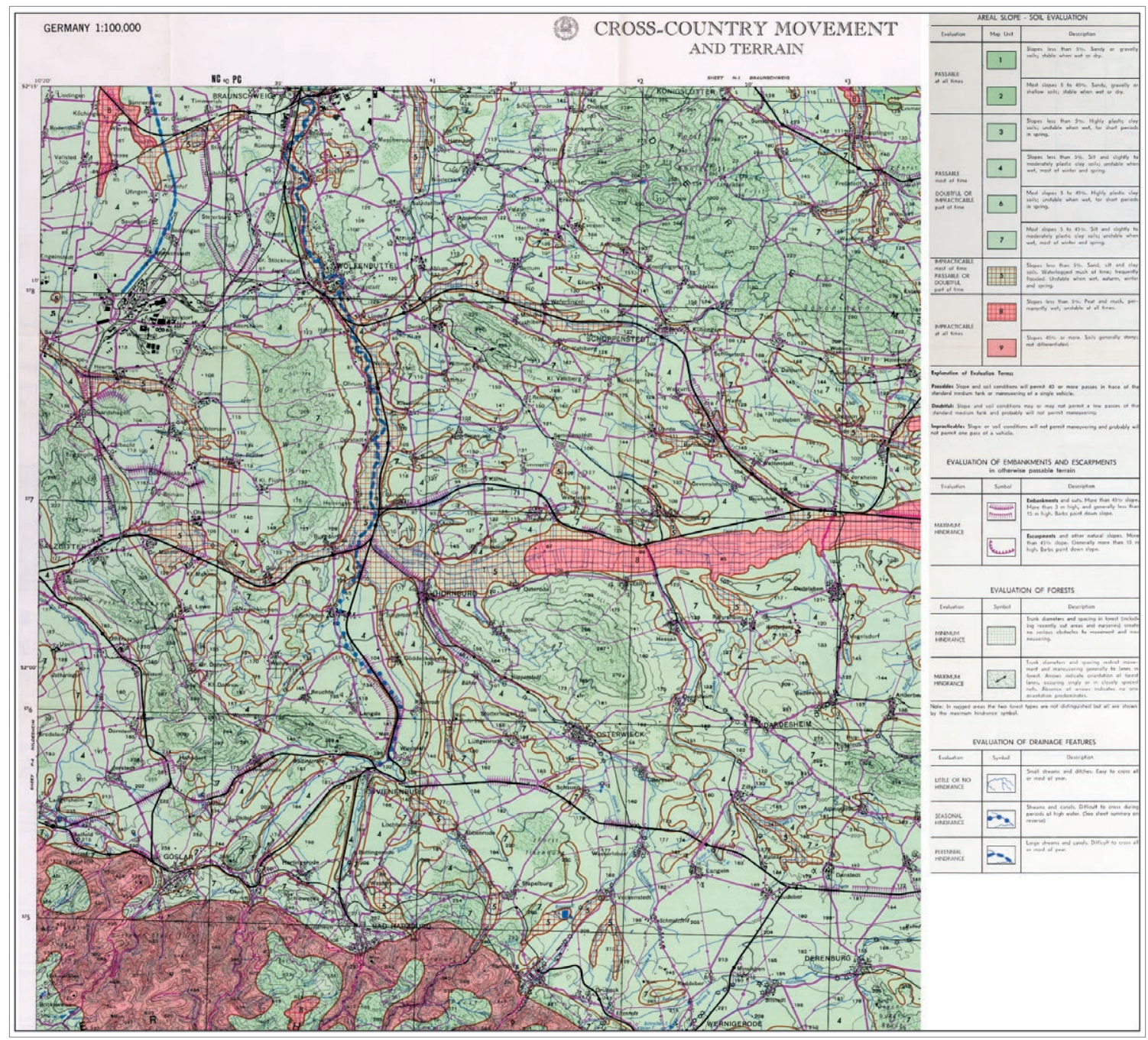

Fig. 6 Example of trafficability map for operational level of decision-making, Section of Sheet P 5 Series M641 (CCM), Cross-Country Movement and Terrain Map, Halberstadt, Germany, 1958, made by the U.S. Army.

SI.6. Primjer karte prohodnosti vozila na operativnoj razini odlučivanja. Dio lista P 5 Serija M641 (CCM), Terenska pokretljivost vozila i karta zemljišta, Halberstadt, Njemačka, 1958, izrađena od strane vojske SAD-a.

Source / Izvor: Production of Cross-Country (1959, Appendix I) 
son and Hägerstrand (2005), Stahl (2005), Pimpa (2012), and Han et al. (2014). Furthermore, interactive applications enable the integration of dynamic factors in real time, such as the amount of precipitation predicted by the weather forecast (Schreier and Lavkulich, 1978; Wawer et al., 2003; Grogan, 2009). In accordance with the dynamics, or the needs of modern military forces for obtaining real-time information, interactive applications are increasingly used at the tactical level of operations, while cartographic products are dominant at the operational and strategic levels. su Gustafsson i Hägerstrand (2005), Stahl (2005), Pimpa (2012), Han i dr. (2014). Interaktivne aplikacije omogućuju i integraciju dinamičnih čimbenika u realnom vremenu, kao što je npr. količina padalina predviđena vremenskom prognozom (Schreier i Lavkulich, 1978; Wawer i dr., 2003; Grogan, 2009). Sukladno dinamici, odnosno potrebama modernih vojnih snaga za dobivanjem informacija u realnom vremenu, interaktivne aplikacije u većoj su upotrebi na taktičkoj razini operacija, dok kartografski proizvodi prevladavaju na operativnoj i strateškoj razini upravljanja.
H Heštera M. Pahernik

Physicalgeographic factors of terrain trafficability of military vehicles according to Western World methodologies

Fizičko-geografski čimbenici terenske prohodnosti vojnih vozila prema metodologijama zapadnoga svijeta
Fig. 7 Example of trafficability map for tactical level of decision-making, CrossCountry Movement map at scale 1:25,000, Tišnov area (Czech Republic).

SI. 7. Primjer karte prohodnosti vozila na taktičkoj razini odlučivanja. Karta terenske mobilnosti vozila u mierilu 1:25 000 za područje Tišnova (Češka).

Source / Izvor: Rybansky et al. $(2015,7055)$

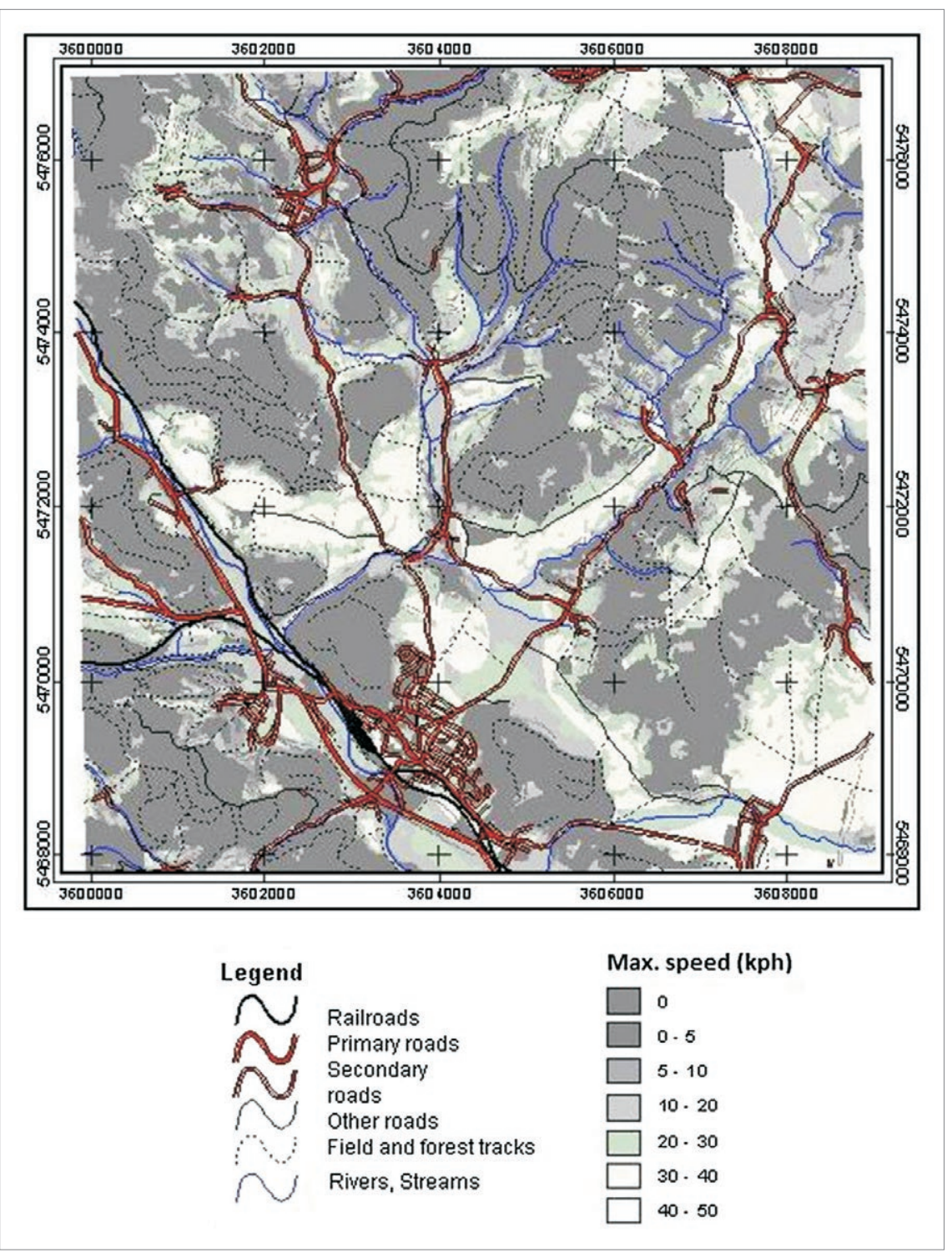




\section{Conclusion}

Analyses of cross-country mobility of military vehicles in modern military operations are defined using mathematical models within geo-informatics systems. The models are based on research of factors that influence mobility in certain geographic environments. Once the studies have been carried out, a universal model is created for specific vehicles and their use in specific weather conditions, based on known relations and spatial analysis algorithms. The quality of output information depends on the compatibility of the mobility parameters within the model, on one hand, and the quality of the analysed input data, on the other. During the planning and defining of the research objectives of vehicle terrain trafficability factors, it is necessary to clearly define the purpose and the scope of the final results. The highest level of detail and accuracy of data is required for ride simulators and interactive applications used in movement planning for autonomous off-road vehicles. The required accuracy and precision of the data are directly correlated with the map scale. The results and the quality of the research are directly dependent on the number of factors, and the accuracy and precision of data included in the models. In turn, their number and quality depend on measurements and the availability of data. In modelling, it is not possible to achieve absolute accuracy in calculations, exactly corresponding to the actual situation on the ground. Numerous authors have carried out research investigating the influence of certain factors on the vehicles movement, but the biggest challenge has been the process of unification and definition of the aggregate impact of all the elements on the vehicle. GIS provides a convenient environment for solving the problems of all recognised vehicle trafficability factors. On its platform, it combines the processes of structuring, organizing, analysing and modelling of the data, and enables evaluation, standardisation, and visualisation of vehicle terrain trafficability. Research of physical-geographic parameters within existing mobility models have outlined the importance of certain parameters in common use. As far as the primary group of factors is concerned, we can single out those factors which are present in more than $60 \%$ of the 25 observed

\section{Zaključak}

Analize terenske prohodnosti vojnih vozila $\mathrm{u}$ suvremenim vojnim operacijama definirane su matematičkim modelima unutar geoinformacijskih sustava. Modeli se temelje na različitim istraživanjima utjecaja parametara o kojima ovisi prohodnost u pojedinim geografskim okolišima. $\mathrm{Na}$ temelju dobivenih odnosa i odabirom pojedinih algoritama prostorne analize uspostavlja se opći model prohodnosti za pojedina vozila u određenim vremenskim uvjetima. Kvaliteta izlazne informacije ovisi o usklađenosti parametara prohodnosti unutar modela s jedne strane i kvalitete ulaznih podataka koje model analizira s druge strane. Prilikom planiranja i definiranja cilja istraživanja čimbenika terenske prohodnosti vozila izrazito je važno jasno odrediti svrhu i namjenu rezultata istraživanja. Najviša razina detalja i točnosti podataka potrebna je simulatorima terenske vožnje i interaktivnim aplikacijama za planiranje aktivnosti autonomnih terenskih vozila. Zahtijevana točnost i preciznost podataka u izravnoj je korelaciji s mjerilom karte. Rezultati i kvaliteta istraživanja izravno su ovisni o broju čimbenika te točnosti i preciznosti podataka uključenih u modele. Njihova brojnost i kvaliteta ovisi o provedenim mjerenjima i dostupnosti podataka. U modeliranju nikada nije moguće postići apsolutnu točnost izračuna koji bi u konačnici odgovarali stvarnoj situaciji. Brojni su autori proveli istraživanja utjecaja pojedinih čimbenika na kretanje vozila, ali je najveći znanstveni izazov proces objedinjavanja i definiranja zbirnoga utjecaja svih elemenata prostora na kretanje vozila. GIS osigurava pogodno okruženje za rješavanje problema svih prepoznatih čimbenika terenske prohodnosti vozila. Na svojoj platformi objedinjuje procese strukturiranja, organizacije, analize i modeliranja podataka te omogućuje evaluaciju, standardizaciju i vizualizaciju terenske prohodnosti vozila. Provedena istraživanja fizičko-geografskih parametara unutar postojećih modela prohodnosti jasno su upozorila na važnost pojedinih parametara koji se koriste u modelima. Tako se u primarnu skupinu čimbenika mogu izdvojiti oni koji su zastupljeni u više od $60 \%$ od promatranih 25 modela terenske prohodnosti vozila - to su nagib padine, hrapavost 
models of terrain trafficability of military vehicles. These factors are slope, surface roughness, soil type according to USCS classification, rating cone index, soil moisture, water courses, vegetation type, and trunk spacing and diameter in forests. The secondary group comprises the factors that are represented in $40 \%$ to $60 \%$ of the models, including the depth of the soil, freezing and thawing depths of the soil, as well as the types of forests. Other parameters represented in less than $40 \%$ of the models such as topographic wetness index, surface slipperiness, porosity and permeability of the soil, snow depth, type of the river bed bottom, and so on, can be considered the corrective factors for the most accurate models. The link between the groups of factors and models at strategic, operational, and most detailed tactical levels is clearly evident. Further research within this multidisciplinary domain can be accomplished with new data sources and empirical field research, in order to improve previously defined parameters within existing models. To date, no one has compared (in literature) any of the aforementioned models in the same area. New research should focus on refinement, and explore the accuracy of models and obtained results. The results of such research could start scientific discussions initiated by the fact that the models could be compared, despite having been made on the basis of different methods and approaches. However, in order to be able to compare them, testing should be carried out with the same vehicle types, the same drivers, and with the same accuracy and quality of the input data. The basic problem in parameter modelling is the difficulty in separating each individual factor and accurately defining its deceleration effect on the vehicle in actual situations. It is particularly difficult to predict vehicle deceleration due to the combined impact of two or more factors simultaneously. Therefore, all combinations should be investigated on all types of vehicles. That said, if all of the aforementioned processes were to be performed according to the same methodology, the process would require a lot of time and money. površine, vrsta tla prema USCS klasifikaciji, indeks nosivosti tla, vlažnost tla, vodotoci, tip vegetacije te razmak i promjer stabala u šumskim okolišima. U sekundarnu skupinu čimbenika mogu se uvrstiti oni koji su zastupljeni u $40 \%$ do $60 \%$ modela, a tu spadaju dubina tla, dubina smrzavanja i odmrzavanja tla i vrsta šume. Ostali parametri, zastupljeni u manje od $40 \%$ modela - topografski indeks vlažnosti, klizanje, poroznost i propusnost tla, dubine snijega, tip dna korita vodotoka i sl. mogu se smatrati korektivnim čimbenicima za modele najviše preciznosti. Jasno da se pri tome odmah uočava poveznica navedenih skupina čimbenika s modelima strateške, operativne i najdetaljnije taktičke razine. Prostor za daljnja istraživanja toga multidisciplinarnog područja moguće je pronaći u primjeni novih izvora podataka i empirijskih terenskih istraživanja s ciljem poboljšanja prethodno definiranih parametara unutar postojećih modela. U do sada objavljenoj znanstvenoj literaturi ne postoje rezultati usporedbe modela na istom području. Trebalo bi istražiti mogućnost usporedbe točnosti modela i dobivenih rezultata. Rezultati bi u svakom slučaju pokrenuli znanstvenu raspravu s obzirom na činjenicu da su modeli rađeni prema različitim metodama i one bi kao takve bile usporedive. Provedbom testiranja s istim tipovima vozila, istim vozačima i jednakom točnošću i kvalitetom ulaznih podataka mogli bismo bolje međusobno usporediti točnost različitih modela. Osnovni je problem pri definiranju parametara u modelima u tome što je teško izdvojiti svaki čimbenik zasebno i točno utvrditi koliko on u konačnici usporava vozilo i utječe na njegovu krajnju brzinu u stvarnoj situaciji. Posebice je teško utvrditi usporenje uzrokovano kombinacijom interakcije dvaju ili više čimbenika istodobno, pri čemu se još treba dodati i činjenica da bi sve kombinacije trebalo istražiti i na svakom pojedinom tipu vozila. Zaključno, proces istraživanja svega prethodno navedenog prema istovjetnoj metodologiji istraživanja zacijelo iziskuje mnogo vremena i financijskih sredstava.
H Heštera

M. Pahernik

Physicalgeographic factors of terrain trafficability of military vehicles according to Western World methodologies

Fizičko-geografski čimbenici terenske prohodnosti vojnih vozila prema metodologijama zapadnoga svijeta 
GEOGRAFSKI

GLASNIK

80/2, 5-31 (2018.)

\section{Literature} Literatura
Affleck, R. T., Melloh, R. A., Shoop, S. A., 2009: Cross-country mobility on various snow conditions for validation of a virtual terrain, Journal of Terramechanics 46 (4), 203-210, DOI:10.1016/j.jterra.2008.12.005.

Ahlvin, R. B., Haley, P. W., 1992: NATO Reference Mobility Model Edition II, NRMM II Users's guide, Wareways Experiment Station, Corps of Engineers, Vicksburg.

Al-Hasan, S., Vachtsevanos, G., 2002 Intelligent route planning for fast autonomous vehicles operating in a large natural terrain, Robotics and Autonomous Systems 40 (1), 1-24, DOI:10.1016/ S0921-8890(02)00208-7.

Albert, M., Koenig, G., Mason, G., 2000: Development of a FAST all-seasons model for the state of the ground, in: Proceedings of the 2000 Winter Simulation Conference (eds. Joines J. A. et al), IEEE, Orlando, 1010-1019.

Andersen, H.-E., McGaughey, R. J., Carson, W. W., Reutebuch, S. E., Mercer B., Allan, J., 2003: A comparison of forest canopy models derived from LIDAR and INSAR data in a Pacific Northwest conifer forest, ISPRS Archives 34 (3/ W13), 211-217.

Atkinson, D. M., Deadman, P., Dudycha, D., Traynor, S., 2005: Multi-criteria evaluation and least cost path analysis for an arctic all-weather road, Applied Geography 25 (4), 287-307, DOI:10.1016/j.apgeog.2005.08.001.

Bacon, S. N., McDonald, E. V., Baker, S. E., Caldwell, T. G., Stullenbarger, G., 2008: Desert terrain characterization of landforms and surface materials within vehicle test courses at U.S. Army Yuma Proving Ground, USA, Journal of Terramechanics 45 (5), 167-183, DOI:10.1016/j.jterra.2008.09.005.

Baylot, E. A., Gates, B. Q. Green, J. G., Richmond, P. W., Goerger, N. C., Mason, G. L., Cummins, C.L, Bunch, L. S., 2005: Standard for Ground Vebicle Mobility, U.S. Army Corps of Engineers, Vicksburg.

Becker, C. M., Els, P. S., 2014: Profiling of rough terrain, International Journal of Vehicle Design 64 (2/3/4), 240, DOI:10.1504/IJVD.2014.058500.

Bekker, M. G., 1956: Theory of Land Locomotion, University of Michigan Press, Ann Arbor.
Birkel, P. A., 2003: Terrain Trafficability in Modeling and Simulation, Technical paper Sedris (1), 1-40.

Borisov, M., Banković, R., Drobnjak, S., 2010: Evaluacija morfometrijskih karakteristika zemljišta pri izradi karte tenkoprohodnosti, Vojnotehnički glasnik 1 (11), 62-80.

Bozdech, G. W., 2012: A GPS-based Mobility Power Model for Military Vebicle Applications, University of Tennessee, Knoxville.

Bruzese, V. M., 1989: Terrain analysis and geographic information systems, Oregon State University, Corvallis.

Campbell, D. M. H., 2012: TRAIL: Optimizing trail locations by terrain conditions and other considerations, at high resolution, The University of New Brunswick, Fredericton.

Clausewitz,C.,1997: On war, Wordsworth, Hertfordshire.

Dawkins, J. J., 2011: Terrain Characterization and Roughness Estimation for Simulation and Control of Unmanned Ground Vehicles, Auburn University, Auburn.

Densham, P. J., 1991: Spatial decision support systems, in: Geographical Information Systems: Principles and Applications (eds Maguire, D. J. et al.), Longman Scientific \& Techincal, Essex, 403-412.

Donlon, J. J., Forbus, K. D., 1999: Using a Geographic Information System for Qualitative Spatial Reasoning about Trafficability, in: Proceedings of QR99, The International Workshop on Qualitative Reasoning, Cognitive Systems Division of the Department of Electrical Engineering and Computer Science, Loch Awe, 1-11.

Durst, P. J., Mason, G. L., McKinley, B., Baylot, A., 2010: Predicting RMS surface roughness using fractal dimension and PSD parameters, Journal of Terramechanics 48 (2), 105-111, DOI:10.1016/j.jterra.2010.05.004

Earl, R., 1997: Prediction of trafficability and workability from soil moisture deficit, Soil and Tillage Research 40 (3-4), 155-168, DOI:10.1016/S01671987(96)01072-0.

Eichrodt, A.W., 2003: Development of a spatial trafficability evaluation system, ETH, Zurich.

Frankenstein, S., 2008: FASST Soil Mois- ture, Soil Temperature: Original Versus New, Engineer Research and Development Center, Vicksburg.

Frankenstein, S., Koenig, G., 2004a FASST Vegetation Models, Cold Regions Research and Engineering Laboratory, Vicksburg.

Frankenstein, S., Koenig, G., 2004b: Fast All-season Soil STrength (FASST), Cold

Regions Research and Engineering Laboratory, Vicksburg.

García-Gaines, R. A., Frankenstein, S., 2015: USCS and the USDA Soil Classifcation System, Development of a Mapping Scheme, Cold Regions Research and Engineering Laboratory, Vicksburg.

George, A. K., Singh, H., Dattathreya, M. S., Meitzler, T. J., 2017: A Fuzzy Simulation Model for Military Vehicle Mobility Assessment, Advances in Fuzzy Systems 2017, 1-12, DOI:https://doi. org/10.1155/2017/3982753.

Grabau, W. E., 1964: Terrain evaluation for mobility purposes, Journal of Terramechanics 1 (2), 22-32, DOI:10.1016/0022-4898(64)90062-X.

Grandjean, G., Angeliaume, S., Hohmann, A., Mardhel, V., Bourguignon, A., Courbouleix, S., Chanteclerc, M., Nouvel, J. F., Grima, M., Saporiti, N., Rousselin, T., Yesou, H., Uribe, C., Schaefer, G., N'Guyen, T., Champigny, P., Vandenberghe, F., 2009: The ECORS system: A mobility decision-making tool based on earth observation data, in: International Geoscience and Remote Sensing Symposium (IGARSS), IEEE, Cape Town, 355-358, DOI:10.1109/ IGARSS.2009.5417657

Grogan, A., 2009: Creating a Spatial Analysis Model For Generating Composite Cost Surfaces to Depict Cross Country Mobility In Natural Terrain, in: ASPRS/ MAPPS 2009 Fall Conference, American Society for Photogrammetry \& Remote Sensing, San Antonio, 1-11.

Gumoś, A. K., 2005: Modelling the Cross-Country Trafficability with Geographical Information Systems, Linköpings universitet, Linköping.

Gustafsson, K., Hägerstrand, J., 2005 Development of a neighbourhood graph for traficability analysis, FOI - Swedish Defence Research Agency, Linköping.

Haley, P. W., Jurkat, P., Brady, P., 1979a: NATO Reference Mobility Model, Edition I, Users Guidel, Vol 1, TARAD- 
COM Laboratory, Warren.

Haley, P. W., Jurkat, P., Brady, P., 1979b: NATO Reference Mobility Model, Edition I, Users Guidel, Vol 2, TARADCOM Laboratory, Warren.

Han, D. H., Kim, Y. D., Lee, J. Y., 2014: Multiple-criterion shortest path algorithms for global path planning of unmanned combat vehicles, Computers and Industrial Engineering 71 (1), 57-69, DOI:10.1016/j.cie.2014.02.013.

Handke, A., Butikofer, M., 1994: Computer-aided Mobility Prognosis of Vehicles in the Field, in: 6th European ISTVS Conference, ISTVS, Vienna, 135-150.

Hetherington, J. G., Smith, P. D., 1986: The survivability and mobility of armoured fighting vehicles -Tuition using a simple computer program, Journal of Terramechanics 23 (3), 131-140.

Hintze, D., 1991: The Prediction of Soil Strength with the Aid of Climatic Data, in: 5th European conference, ISTVS, Budapest, 17-25.

Hofmann, A., Hoskova-Mayerova, S., Talhofer, V., 2013: Usage of fuzzy spatial theory for modelling of terrain passability, Advances in Fuzzy Systems 2013, 1-7, DOI:10.1155/2013/506406.

Hofmann, A., Hošková-Mayerová, Š., Talhofer, V., Kovařík, V., 2015: Creation of models for calculation of coefficients of terrain passability, Quality \& Quantity 49 (4), 1679-1691, DOI:10.1007/ s11135-014-0072-1.

Hohmann, A., Grandjean, G., Mardhel, V., Schaefer, G., Desramaut, N., 2013: A GIS-based Vehicle Mobility Estimator for Operational Contexts, Transactions in GIS 17 (1), 78-95, DOI:10.1111/ j.1467-9671.2012.01351.x.

Horttanainen, P., Virrantaus, K., 2004: Uncertainty evaluation of terrain analysis results by simulation and visualization, in: Proc. 12th Int. Conf. on Geoinformatics - Geospatial Information Research: Bridging the Pacific and Atlantic (eds. Brandt, S.), University of Gävle, Gävle, 473-480.

Hoškova-Mayerova, Š., Talhofer, V., Hofmann, A., 2010: Mathematical modell used in decision-making process with respect to the reliability of geo database, Procedia Social and Behavioral Sciences 9, 1652-1657, DOI:10.1016/j. sbspro.2010.12.381.
Hubacek, M., Ceplova, L., Brenova, M., Mikita, T., Zerzan, P., 2015: Analysis of Vehicle Movement Possibilities in Terrain Covered by Vegetation, in: International Conference on Military Technologies (eds. Krivanek, V.), University of Defence, Brno, 301-305.

Intelligence preparation of the battlefield, Field Manual FM 34-130, Headquaters, Department of the Army, Washington D.C., 1994.

Johnson, D.W., 1921: Battelfields of the World War: A Study in military geography, Oxford University Press, New York.

Jomini, A.H.,1838: Precis de l'art de la guerre, Anselin, Paris.

Jurkat, M. P., Nuttall, C.J., Haley, P.W., 1975: The AMC '74 mobility model, US Army Tank Automotive Command, Warren.

Kirkland, J. L., 1981: Remote Sensing of Soil Trafficability Factors, in: Seventh International Symposium Machine Processing of Remotely Sensed Data (eds. Burroff, P.G., Morrison, D.B.), Purdue University, West Lafayette, 454-463.

Knob, M. J., 2010: Estudo de trafegabilidade aplicado a veículos de roda em transporte e tração, Universidade Federal de Santa Maria, Santa Maria.

Kourdian, R., 2009: Analyse de la traficabilité en zone tropicale par imagerie spatiale optique et radar. Application au Tchad méridional, Géosciences et Ressources Naturelles, Paris.

Kristalova, D., 2015: Evaluation Of The Data Applicable For Determining The Routes Of Movements Of Military Vehicles In Tactical Operation, in: International conference KNOWLEDGE-BASED ORGANIZATION, De Gruyter, Berlin, 699-705, DOI:10.1515/kbo-2015-0118.

Kruse, F. A., Boardman, J.W., Lefkoff, A B., 2000: Extraction of compositional information for trafficability mapping from hyperspectral data, in: Algorithms for Multispectral, Hyperspectral, and Ultraspectral Imagery VI (eds. Shen, S.S., Descour M.R.), SPIE 4049, Orlando, 262-273, DOI:10.1117/12.410348

Kuckelkorn, L., 1942: Befahrbarkeitskarte Libyen 1:3.000.000, Karte der Wehrgeologenstelle (12) vom März 1942, Heringen Collection Archive, Bundeswehr Geoinformation Center, Euskirchen.
Lantz, F., Edlund, S., Jungert, E., 2005: Context Fusion for Driveability Analysis, in: 8th International Conference on Information Fusion, IEEE, Philadelphia, 1264-1271, DOI:10.1109/ ICIF.2005.1592002.

Laskey, K. B., Wright, E. J., da Costa, P. C. G., Costa, P. C. G., 2010: Envisioning uncertainty in geospatial information, International Journal of $A$ proximate Reasoning 51 (2), 209-223, DOI:10.1016/j.ijar.2009.05.011.

Leighty, R. D., 1965: Terrain mapping from aerial photography for purposes of vehicle mobility, Journal of Terramechanics 2 (3), 55-67, DOI:10.1016/00224898(65)90023-6.

Lessem, A., Ahlvin, R., Mason, G., 1996: Stochastic vehicle mobility forecasts using the NATO reference mobility model, Journal of Terramechanics 33 (6), 273-280, DOI:10.1016/S00224898(97)00010-4.

Li, Q., Ayers, P. D., Anderson, A. B., 2007: Modeling of terrain impact caused by tracked vehicles, Journal of Terramechanics 44 (6), 395-410, DOI:10.1016/j. jterra.2007.09.001.

List of Publications of the U.S. Army Engineer Waterways Experiment Station, Volume II (ITL-93-1), US Army Corps of Engineers, Vicksburg, 1993.

Loomer, S., 1987: Computer-assisted terrain analysis on a microcomputer, in: Proceedings of the International Symposium on Computer-Assisted Cartography, Auto-Carto VIII, Baltimore, 437-444.

Lubello, D., 2008: A Rule-based SDSS for integrated forest harvesting planning, Universitá degli studi di Padova, Padova.

Malm, F., 2018: One hundred years of cross-country mobility prediction in Germany, in: Military Aspects of Geology: Fortification, Excavation and Terrain Evaluation (eds. Rose, E.P.F. et al.), Geological Society, London, https://doi. org/10.1144/SP473.7.

Mason, G., Ahlvin, R., Green, J., 2001: Short-Term Operational Forecasts of Trafficability, U.S. Army Corps of Engineers, Washington, D.C..

Mason, G. L., Gates, B. Q. Moore, V. D., 2012: Determining forces required to override obstacles for ground vehicles, Journal of Terramechanics 49 (3-4), 191196, DOI:10.1016/j.jterra.2012.04.001.
H Heštera

M. Pahernik

Physicalgeographic

factors of terrain

trafficability of

military vehicles

according to

Western World

methodologies

Fizičko-geografski čimbenici terenske prohodnosti vojnih vozila prema metodologijama zapadnoga svijeta 
GEOGRAFSKI

GLASNIK

80/2,5-31 (2018.)
Mason, G. L., Moore, D. W., Brandon, G. M., Leese, D. L., 2003: Data Collection and Analysis of Moisture and Soil Strength Information for Validation of New State-of-the-Ground Models, Engineer Research and Development Center, Vicksburg.

Messmore, J. A., 1982: Terrain Analysi Procedural Guide for Drainage and Water Resources, U.S. Army Corps of Engineers, Fort Belvoir.

Messmore, J. A., Vogel, T. C., Pearson, A. R., 1981: Terrain analysis procedural guide for vegetation, U.S. Army Corps of Engineers, Fort Belvoir.

Military Geographic Intelligence (Terrain), Field Manual FM 30-10, Headquaters, Department of the Army, Washington D.C., 1972.

Mintzer, O., Messmore, J. A., 1984: Terrain analysis procedural guide for surface configuration, U.S. Army Corps of Engineers, Fort Belvoir.

Mohamad Rabab, M. Z., 2002: Development of Terrain Analysis Database Using Military Geographic Information System, Universiti Putra Malaysia, Serdang.

Mohtashami, S., Bergkvist, I., Löfgren, B., Berg, S., 2012: A GIS Approach to Analyzing Off-Road Transportation: a Case Study in Sweden, Croatian Journal of Forest Engineering 33 (2), 275-284.

Murphy, N. R., Randolph, D. D., 1994: A Limited NRMM Validation Study for ISTVS, US Army Corps of Engineers, Vicksburg.

Pahernik, M., Tuta, J., Kovačević, D., 2006: Determination of Terrain Serviceability of Military Vehicles by GIS Relief Analysis, Promet - Traffic E Transportation 18 (6), 387-394.

Pearson, A. R., Wright, S. J., 1980: Synthesis guide for cross-country movement, U.S Army Corps of Engineers, Fort Belvoir.

Pike, R. J.,1995: Geomorphometry - progress, practice, and prospect, Zeitschrift fur Geomorphologie, Suppl., 101, 221-238.

Pimpa, W., 2012: Terrain analysis for path finding of combat cross-country movement, Suranaree University of Technology, Nakhon Ratchasima.

Pimpa, W., Sarapirome, S., Dasananda, S., 2014: GIS application to development of military cross-country movement maps at Mae Sot District,
Western Thailand, Suranaree Journal of Schreier, H., Lavkulich, L. M., 1978 Science and Technology 21 (3), 215-232, DOI:10.14456/sjst.2014.16.

Planning and design of roads, airfields, and heliports in the theater of operations-road design, Field Manual FM 5-430-001, Headquarters, Department of the Army, Washington, D.C., 1994.

Prato, C. G., 2009: Route choice modeling: Past, present and future research directions, Journal of Choice Modelling 2 (1), 65-100, DOI:10.1016/S17555345(13)70005-8

Production of Cross-Country Movement Studies, Engineer Intelligence Guide 31, Chief of Engineers, Department of the Army, Washington D.C., 1959.

Rowland, D., 1972: Tracked vehicle ground pressure and its effect on soft ground performance, in: Proceedings of 4th ISTVS International Conference, ISTVS, Stockholm, 353-384.

Rybansky, M., 2003: Effect of the Geographic Factors on the Cross Country Movement, in: Proceedings of the 21st International Cartographic Conference (ICC) 'Cartographic Renaissance', The International Cartographic Association (ICA), Durban, 2449-2454.

Rybansky, M. 2009: Cross-country movement the impact and evaluation of geographic factors, University of defence in Brno, Brno.

Rybansky,M.,2014: Modelling of the optimal vehicle route in terrain in emergency situations using GIS data, IOP Conference Series: Earth and Environmental Science 18, 1-6. DOI:10.1088/17551315/18/1/012131

Rybansky, M., Hofmann, A., Hubacek, M., Kovarik, V., Talhofer, V., 2015: Modelling of cross-country transport in raster format, Environmental Earth Sciences 74 (10), 7049-7058, DOI:10.1007/ s12665-015-4759-y.

Saarilahti, M., 2002: Soil interaction model, Development of a protocol for ecoefficient wood harvesting on sensitive sites (ECOWOOD), Helsinki.

Sadiya, T. B., Eta, J., Oladiti, I., James, G., Shaba, H. A., Mamfe, V., Muhammad, S.O., Xu, M., Sha, J. , Sanusu, M., 2017: Military Terrain Trafficability Analysis for North-East Nigeria: A GIS and Remote Sensing-Based Approach, IOSR Journal of Mobile Computing \& Application 4 (1), 34-46, DOI:10.9790/0050-04013446.
A Numerical Terrain Classification Scheme for Off-Road Terrain Trafficability Assessments, Geoforum 9 , 225-234.

Shoop, S. A., 1993: Terrain Characterization for Trafficability, US Army Corps of Engineers, Hanover.

Shoop, S. A., Affleck, R., Collins, C., Larsen, G., Barna, L., Sullivan, P., 2005: Maneuver analysis methodology to predict vehicle impacts on training lands, Journal of Terramechanics 42 (3-4), 281303, DOI:10.1016/j.jterra.2004.10.012.

Shoop, S. A., Richmond, P. W., Lacombe, J., 2006: Overview of cold regions mobility modeling at CRREL, Journal of Terramechanics 43 (1), 1-26, DOI:10.1016/j.jterra.2004.08.004. Rudak, M., Colvin, N., Gates, C., 2003: Trafficability Analysis Engine, CROSSTALK The Journal of Defense Software Engineering (June), 28-30.

Smith, M. H., Meyer, M. P., 1973: Automation of a model for predicting soil moisture and soil strenght (SMSP model), Army Engineer Waterways Experiment Station, Vicksburg.

Stahl, C. W., 2005: Accumulated Surfaces Eे Least-Cost Paths: GIS Modeling for Autonomous Ground Vebicle (AGV) Navigation, Virginia Polytechnic Institute and State University, Blacksburg.

Sullivan, P. M., Renfroe, N. A., Albert, M. R., Koening, G. G., Peck L., O’Neill, L., K., 1997: Soil moisture strength prediction model version II (SMSP II), U.S. Army Engineer Waterways Experiment Station, Vicksburg.

Suvinen, A., 2006: A GIS-based simulation model for terrain tractability, Journal of Terramechanics 43 (4), 427-449, DOI:10.1016/j.jterra.2005.05.002.

Suvinen, A., Saarilahti, M., 2006: Measuring the mobility parameters of forwarders using GPS and CAN bus techniques, Journal of Terramechanics 43 (2), 237-252, DOI:10.1016/j.jterra.2005.12.005

Suvinen, A., Saarilahti, M., Tokola, T., 2003: Terrain mobility model and determination of optimal off-road route, in: The 9th Scandinavian Research Conference on Geographical Information Science (eds. Virrantaus, K., Tveite, H.), Helsinki University of Technology, Espoo, 251-259.
Slocum, K., Surdu, J. R., Sullivan, J., 
Talhofer, V., Hofmann, A., Kratochvil, V., Hubacek, M., Zerzan, P., 2015: Verification of Digital Analytical Models: Case Study of the Cross-Country Movement, in: ICMT 2015 - International Conference on Military Technologies 2015 (eds. Krivanek V.), Faculty of Military Technology, Brno, 1-7, DOI:10.1109/ MILTECHS.2015.7153664.

Tarapata, Z., 2003: Military route planning in battlefield simulation: effectiveness problems and potential solutions, Journal of Telecommunications and Information Technology 4, 47-56.

Terrain Analysis, Field Manual FM 5-33, Headquaters, Department of the Army, Washington D.C., 1990.

Tzu, S., 2009: Umijeće ratovanja, Mozaik knjiga, Zagreb.
Vrščaj, B., Godeša, T., 2010: GIS modeliranje prehodnosti terena za potrebe slovenske vojske, GIS v Sloveniji 20092010, 41-53.

Waldock, A., Corne, D., 2011: Multiple Objective Optimisation applied to Route Planning, in: Proceedings of the 13th Annual Genetic and Evolutionary Computation Conference (eds. Krasnogor, N.), ACM, Dublin, 1827-1834, DOI:10.1145/2001576.2001821.

Wawer, R., Nowocien, E., Lopatka, A. 2003: An approach to dynamic trafficability mapping as a component of battle management systems, in: Soil trafficability - challenges for soil and vebicles (eds. Reintam, E., Saumets, A.), Estonian National Defence College, Estonian University of Life Sciences, Tartu, 48-56.
Weiss, R. A., 1981: Terrain microroughness and the dynamic response of vehicles, in: Transactions of the twenty-seventh Conference of army mathematicians, West Point, New York, 448-535.

Wong, J. Y., 2001: Theory of ground vebicles, Third Edition, John Wiley \& Sons INC, New York, DOI:10.1017/ CBO9781107415324.004.

Wright, J. S., Vogel, T. C., Pearson, A. R., Messmore, J. A., 1981: Terrain analysis procedural guide for soil, US Army Corps of Engineers, Fort Belvoir.

Wynn, L. K., 1985: Comparison of Manually Produced and Automated Cross Country Movement Maps Using Digital Image Processing Techniques, NASA, Pasadena.
H Heštera

M. Pahernik

Physicalgeographic

factors of terrain

trafficability of

military vehicles

according to

Western World

methodologies

Fizičko-geografski čimbenici terenske prohodnosti vojnih vozila prema metodologijama zapadnoga svijeta
Hrvoje Heštera hrvoje.hestera@morh.hr prof. geografije, Hrvatsko vojno učilište „Dr. Franjo Tuđđman”, llica 256b, 10000 Zagreb, Hrvatska

Mladen Pahernik mladen.pahernik@morh.hr doc. dr. sc., Hrvatsko vojno učilište „Dr. Franjo Tuđđman”, llica 256b, 10000 Zagreb, Hrvatska
Authors

Autori 